\title{
The archaeology of fish and fishing on the central coast of California: The case for an under-exploited resource
}

\author{
Terry L. Jones ${ }^{\mathrm{a}, *}$, Kenneth W. Gobalet ${ }^{\mathrm{b}}$, Brian F. Codding ${ }^{\mathrm{c}}$ \\ a Department of Social Sciences, California Polytechnic State University, San Luis Obispo, CA, United States \\ ${ }^{\mathrm{b}}$ Department of Biology, Emeritus, California State University, Bakersfield, CA 93311-1099, United States \\ ${ }^{\mathrm{c}}$ Department of Anthropology, University of Utah, Salt Lake City, UT, United States
}

\section{A R T I C L E I N F O}

Keywords:

Prehistoric fishing

Fish remains

Technology

Complex hunter-gatherers

Resource depression

Epiphenomenal sustainability

\begin{abstract}
A B S T R A C T
Decades of systematic archaeological investigations highlight the importance of fish and fishing for prehistoric people along the central coast of California, but to date temporal and spatial trends remain unsynthesized. An evaluation of 202,177 fish remains from 86 sites on the central coast of California yielded a sample of 75,532 NISP from temporally and methodologically controlled contexts. Seventynine temporal components demonstrate a 10,000-year history of fishing within estuaries, along the open rocky coast, and on the Monterey Peninsula. Fishes within six taxa dominate the record throughout including New World silversides, small surfperches, and members of the herring family which almost certainly were caught with nets, and rockfish and cabezon which were amenable to individual hook and line capture. The persistent dominance of these fishes suggests that nets and hooks/gorges were employed throughout the sequence along with watercraft. Only very modest changes are apparent between 10,000 and 300 years ago, suggesting continuous harvest of a relatively productive, stable resource that was too abundant to be seriously impacted by pre-European harvesting practices. There is no evidence for gradual or incremental intensification in fishing, rather there are three intervals of change in fish remains and inferred fishing practices that reflect changes in human population and/or environment. There is no compelling evidence for depression of the prehistoric fishery and the record seems to reflect epiphenomenal sustainability related to low human populations and a highly productive, upwelling-fueled, under-exploited fishery. Comparison of the prehistoric record with enormous yields recorded historically further supports this conclusion.
\end{abstract}

\section{Introduction}

More than a century ago ethnographers established that fishdependent hunter-gatherers, like those on the Northwest Coast of North America, were profoundly different from their terrestrial counterparts (see Kelly, 1996; Pálsson, 1988; Plew, 1996), representing what would eventually be classified as "complex foraging." For most of the ensuing century it was often assumed that such adaptations were relatively recent developments-a notion that was supported only by a very limited archaeological record. By the end of the 20th century, however, archaeology demonstrated that such assumptions were unfounded; that coastal adaptations have significant antiquity in North America and beyond, and seem to have facilitated a coastal migration into the New World (Erlandson, 2001, 2002; Erlandson et al., 2007, 2008a, 2011a). In

\footnotetext{
* Corresponding author.

E-mail addresses: Tljones@calpoly.edu (T.L. Jones), kgobalet@csub.edu (K.W. Gobalet), brian.codding@antho.utah.edu (B.F. Codding).
}

light of such recognition archaeologists have been working in earnest to try to understand the energetics of marine resource acquisition and the use of coastal habitats, often employing optimization concepts with archaeological faunal remains. Such models have repeatedly demonstrated their value in furthering the understanding of coastal resource use, and many have led to arguments that marine resources were overexploited prehistorically (Rick and Erlandson, 2008). In California arguments have been advanced for overexploitation of shellfish (Botkin, 1980; Erlandson et al. 2008b; Jones, 1996), marine mammals (Hildebrandt and Jones, 1992, 2002), marine birds (Broughton, 2004; Jones et al., 2008a; Whitaker, 2010); and fish (Broughton, 1994, 1997; Broughton et al., 2015; Salls, 1992). While many early proposals for marine resource overexploitation and resource depression were largely conjectural (Botkin, 1980; Salls, 1992) more recent cases, especially for shellfish, have been bolstered with meaningful empirical evidence (e.g., Erlandson et al., 2008b, 2011b). Solidly supported cases for overexploitation of marine fish, however, are much less common, although Broughton et al. (2015) recently made a 
convincing argument for depression of sturgeon populations prehistorically in San Francisco Bay, superseding an earlier study by Gobalet and Hardin (2009) who were unable to find support for depletion of sturgeons in that area with a meta-analysis. Sturgeon were enormous fish (individuals can reach over $800 \mathrm{~kg}$ ) fish that were probably unusually visible and vulnerable, with low populations uniquely susceptible to overexploitation-akin to the flightless duck that was hunted to extinction prehistorically in California (Jones et al., 2008a). In fact with the initiation of a commercial fishery for sturgeon around 1870 by Euroamericans, it took only 30 years before the population of white sturgeon in the San Francisco dropped to the point that they were considered to be on the brink of extinction and the California legislature temporarily abolished the fishery (Skinner, 1962:84). But in terms of prehistoric depression, sturgeon might best be considered the exception, not the rule. In many other instances, the empirical record seems to suggest that fisheries were essentially unaffected by prehistoric human exploitation - as was the case in South Polynesia (Anderson, 2008), Peru (Reitz et al., 2008), and the Northwest Coast of North America (Butler and Campbell, 2004). That fisheries in some parts of the world at least could withstand continued, substantial harvest over time may help explain the development of complex technologies used to exploit them and the perpetuation of fishing-related cultures. Of all of the marine resources associated with intensive hunter-gatherer economies, fish are linked to the most complex technologies and seem most tightly linked to heightened levels of socio-political complexity as can be seen in both southern (Arnold, 1992, 1995, 2001, 2004; Erlandson and Rick, 2002; Gamble, 2008; Kennett, 2005; Pletka, 2001; Rick, 2007, among others) and northwestern California (Hildebrandt, 1984; Kroeber, 1925; Tushingham, 2009).

Here we report the results of our synthesis of a substantial quantity of fish remains data from the central coast of California undertaken with an eye toward identifying temporal variation that could indicate the relative intensity of fishing and possible overexploitation. The ethnographic record from this area, limited to accounts from two centuries ago, constrains our ability to generate meaningful estimates of the pursuit and processing costs associated with indigenous fishing in pre-modern habitats. Nonetheless, general trends do allow us to roughly approximate the profitability of fishing based on the diversity of the fishes caught and the technology required to catch the fish. We evaluate the possibility of overexploitation with an extensive data set resulting from CRM and other investigations in this region that have produced a substantial quantity of fish remains (here we consider a regional NISP of 202,177 ) representing a 10,000-year record of fishing. To evaluate this sequence we establish methodological and analytical protocols for evaluating a massive fish remains data set in combination with the archaeological record of fishing technology in order to identify possible diachronic variation in fishing patterns. By holding methodological, analytical, and geographic variables constant we aspired to examine the relationship between technological changes and possible shifts in the most abundant species caught in order to determine whether any such changes might reflect overfishing-or whether alternative explanations would be more parsimonious. We conclude that central California fisheries were resilient to overexploitation and that the little diachronic variation that can be identified is better explained with reference to settlement, seasonality and environment. We bolster this assessment with comparison to modern fishing yields that show unequivocally that this regional fishery was one of enormous productivity owing to its position in the western Pacific in a zone of intense upwelling. Unlike Kennett et al. (2008) who found that huge historic changes in the less productive fisheries of southern Mexico were preceded by small-but-noticeable human-induced changes in prehistoric times, we can find no definitive evidence that the fisheries of central coastal California were significantly impacted by humans until the 19th century. These conclusions echo those of Butler and Campbell (2004) who found no evidence for depression of fish resources on the Northwest Coast. Further, at least in the California case, there is no obvious reason to consider this anything other than epiphenomenal sustainability (Smith and Wishnie, 2000) and not a product of deliberate conservation on the part of indigenous fishing people.

\section{General working concepts}

Recent studies seeking to explain the prehistoric impacts of humans on local fauna typically approach the record from the perspective of historical ecology (e.g., Rick et al., 2008) or behavioral ecology (Kennett, 2005). Both examine how the relative abundance of prey species vary through time as a function of human exploitation, but the latter has the benefit of developing clear predictions about which prey people should prefer and how individuals should respond to local environmental variation (Bird and O'Connell, 2006; Codding and Bird, 2015). This is accomplished through the application of formal models, the most common of which is the prey choice model (e.g., Charnov, 1976). From this perspective, if prehistoric fishing strategies were directed toward maximizing harvest rates, then individuals should preferentially target those species that offer the greatest energetic returns and only acquire prey of lower profitability when these high ranking species decline in abundance (see a detailed review by Codding and Bird, 2015). One potential confound that is particularly important to consider with fish involves technology: gaining the highest possible energetic returns may necessitate specific technologies that require significant investment in manufacture and maintenance, which may only be worth it when people allocate large portions of their subsistence time to fishing (Ugan et al., 2003). Thus, both the aspects of the targeted species and the technology needed to capture them are required to understand the profitability of different fishing strategies. As mentioned in the introduction, understanding fishing profitability along the central California coast is not easy given the lack of local quantitative ethnographic data, but we can make some general rankings based on global patterns that co-vary with known targeted species or technological characteristics. Examining variation in the post-encounter return rates for 25 fish prey types from ethnographic observations in Oceania (Bliege Bird and Bird, 1997; Raven, 1990) and experimental studies in North America (Lindstrom, 1996; Thomas, 2008) show that profitability (1) generally increases with fish size and (2) generally increases when caught en masse (e.g., with nets; Fig. 1). This provides two clear ways to rank the available fish taxa based on their profitability. If human fishing pressure results in overexploitation, then the record should show individuals transitioning to lower profitability size classes or technologies through time. If individuals exploit relatively high ranking fish throughout the sequence, then the record should show only limited diachronic change.

\section{Regional working hypotheses}

While the importance of fishing to the insular societies of southern California has been investigated extensively in the last few decades (Arnold, 1992, 1995, 2001, 2004; Erlandson and Rick, 2002; Gamble, 2008; Kennett, 2005; Pletka, 2001; Rick, 2007; Turnbull et al., 2015, among others) the relative significance of fish to foraging groups of the central mainland of California has not been systematically evaluated (although see the recent work by Boone, 2012) in spite of the fact that an archaeological study by Greenwood (1972) demonstrated over 40 years ago that fishing has an antiquity of at least 9000 years in this region. At that time, 

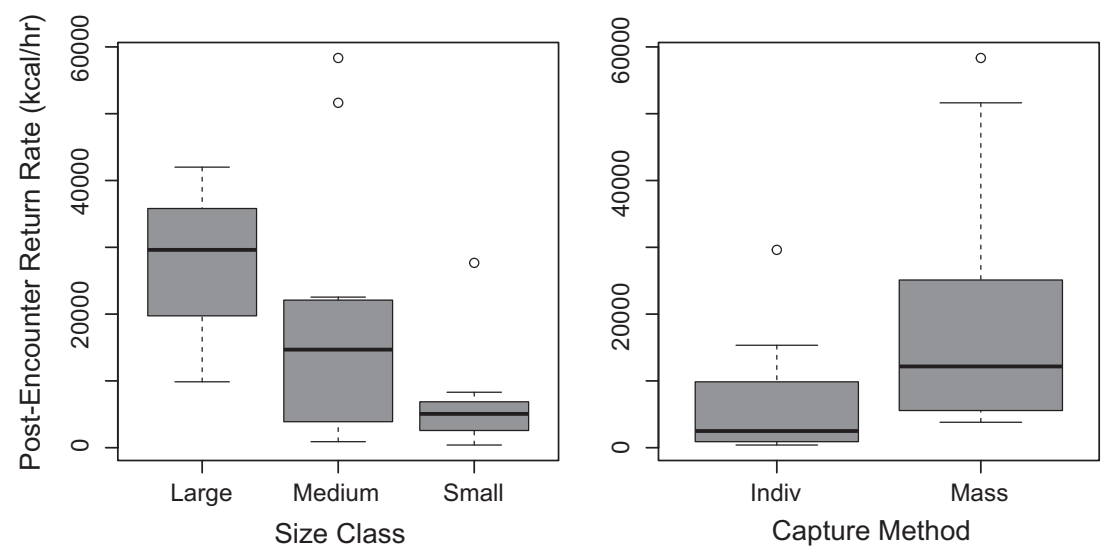

Fig. 1. Post-encounter profitability of (left) and capture technology (right) from ethnographic and experimental studies.

Fitch (1972) showed the diversity of species exploited at one site along one stretch of exposed rocky shoreline (Diablo Canyon) in San Luis Obispo County. Since then, several hundred archaeological sites have been excavated along the central shores of California (see Jones et al., 2007), and while not all of these have produced fish remains, there exists an extensive, unsynthesized body of archaeological data on fish and fishing that represents virtually all major aquatic habitats in the region and nearly all culturallydefined intervals of time for the last 10,000 years. Gobalet and Jones (1995) summarized 78,730 fish remains from 51 of these sites, but the approach at that time was strictly atemporal; they summarized the range and diversity of fishes represented in different prehistoric habitats but with no consideration of variation through time. Gobalet (2000) and Gobalet et al. (2004) added to the data base, but again provided only site species lists and NISP for an audience of biologists.

In the current paper we re-consider the data presented in 1995 , 2000 , and 2004 and supplement it with additional zooarchaeological findings reported in subsequent years, and order all findings chronologically and by habitat, and further consider the chronology of fishing technologies as represented in the regional artifact record. Specifically, we summarize the prehistoric archaeology of fish and fishing for the two counties on the central California coast (Monterey and San Luis Obispo) that have yielded the most fish remains and fishing-related artifacts from well-dated contexts with clearly described methods of recovery and specimen identification.

Fitch (1972) who completed the first important analysis of fish remains in the region also proposed the first interpretations. Based on findings from a column sample processed with $1.0 \mathrm{~mm}$ mesh from the 9000-year sequence at CA-SLO-2 on the exposed rocky coast, he argued that the earliest site inhabitants used only the simplest technology and fished exclusively for species that could be found under exposed rocks and in tidepools and caught by hand. He also suggested that some type of shore-based traps might have been employed, and that simple watercraft were probably used to reach the outer edges of kelp beds. This interpretation is consistent with regional ethnography. Although he did not speculate explicitly about the chronology of watercraft use, Fitch emphasized shoreline-based fishing for the earliest site inhabitants. The only significant change that he detected was an increase in the relative number of fish remains in the upper third of the $3.4 \mathrm{~m}$ deep deposit that he associated with the advent of curved shell fishhooks. Hence the earliest ideas about fishing in the region suggested that two technologies-curved hooks and watercraft-influenced the character of the local marine adaptations.
Since Fitch (1972), much greater antiquity has been recognized for the use of watercraft along the California coast (Des Lauriers, 2010; Erlandson et al., 2007, 2008a, 2011a; Raab et al., 2009, among others). Findings from the Channel Islands indicate that boats of some type were being used $200 \mathrm{~km}$ south of the current study area by 13,000-12,000-years ago (Erlandson et al., 2011a). Jones et al. (2008b) who subsequently analyzed fish remains from CA-SLO-2 that had not been evaluated by Fitch (1972) concluded that it was most likely that site inhabitants had watercraft from the very outset of that mainland occupation. Also, in the Santa Barbara area, particularly on the islands, fish remains became distinctly more abundant in sites over the course of the Holocene (Glassow, 1993) and most scholars believe that increased fishing resulted from the appearance first of shell fishhooks ca. $3000 \mathrm{cal}$ BP and later, better boats (the sewn-plank canoe) ca. 1500 cal BP. This most recent technological transition did not occur on the central coast mainland, however, where the ethnographic record indicates only the use of tule balsa canoes. Whitaker and Byrd (2012), however, suggested that boat use increased on the central coast during the Late Period in order to increase exploitation of shellfish.

McKenzie (2007) proposed a model for the Channel Islands based on experimental fishing with replicated shell hooks in which he suggested that the development of the shell fishhook was a critical turning point in the trajectory of Chumash cultural evolution. While he did not suggest that hooks caused cultural complexity, his findings showed that, relative to the earlier bone gorges, hooks allowed for more effective exploitation of nearshore fisheries which he felt contributed to increased population growth, sedentism, and craft specialization (see Arnold, 1992). The latter developments are not apparent on the central coast mainland, however, or are at best only weakly substantiated. The intensive fisheries and extremely dense concentrations of fish bone found on the Channel Islands (Kennett, 2005; Pletka, 2001; Rick, 2007), seem unique to those insular settings and have not been documented on the central coast mainland. Indeed one purpose of the present paper is to sort out trends over time on the mainland from the more heavily studied and highly publicized findings from the southern California islands.

Codding and Jones (2007) are among authors who have applied human behavioral ecology to central coast fishing strategies. They interpreted the high frequency shell hooks and notched-stone net weights at CA-SLO-9 as reflections of increased hook and line fishing relative to net-based fishing during the Middle-Late Transition, and further attributed the shift to changes in regional social relations caused by drought-related resource scarcity during the Medieval Climatic Anomaly (MCA) which in turn caused men to spend 
more time fishing than hunting. This is also one of several papers where a case has been made for increased fishing during the MCA due to reduced terrestrial productivity (Codding and Jones, 2007; Codding et al., 2010; Jones and Kennett, 1999; Jones and Ferneau, 2002). Joslin (2010) made a similar case for drought-caused subsistence change on the northern San Luis Obispo coast near Cambria. Boone (2012), using a greatly improved regional paleoclimatic sequence, further argued for drought-induced changes in fishing practices in the Monterey Bay area during the MCA.

Boone's (2012) study was also the first in the region to focus almost exclusively on fish remains. Using data from 11 sites in the Monterey Bay area she proposed a trans-Holocene model for fishing that recognized a long-term reliance on watercraft and greater overall importance of fish in the diet early on. She also suggested that fisheries featured mass-capture and greatest variety during the Millingstone/Lower Archaic Period with decreasing species diversity over time. Using a more fine-grained assessment of local habitats than we employ here she developed a patch and decision based model that incorporated paleoenvironmental variation. She recognized a decrease in sharks and rays over time and distinctive changes in habitat choice during the MCA, but no evidence for changes in fishing across the Early-Middle Period transition - a period that some have associated with an intrusion of new cultural groups into the Monterey Bay Area (Breschini and Haversat, 1980, 2011; Dietz, 1987; Moratto, 1984). Indeed culturally-mediated change in fishing represents yet another alternative explanation for variation in fishing practices, particularly in the Monterey Bay area which has long been thought to have witnessed a population replacement with intruding Utian-speaking peoples supplanting earlier speakers of Hokan languages (Kroeber, 1925; see also Codding and Jones, 2013; Golla, 2011).

\section{Contextual background}

\subsection{Aquatic habitats}

Our study area includes the coast encompassing the shorelines of Monterey and San Luis Obispo counties on the central coast of California (Fig. 2). This stretch of the central California coast is marked mostly by relatively small creeks and rivers that drain the ranges that front the Pacific shoreline. The exception to this is the Salinas River, including its two major tributaries, the San Antonio and Nacimiento which drain the interior and the eastern flanks of the South Coast Ranges through the Salinas Valley. The Salinas empties into the Pacific in the central portion of Monterey Bay where it formerly was part of an extensive estuary complex that also includes the lower reaches of the Pajaro River and the Elkhorn Slough lagoon. Fish remains from Elkhorn Slough (Gobalet, $1990,1993)$ and geomorphology indicate that this lagoon once was connected with the Sacramento/San Joaquin rivers (Gordon, 1979; Harden, 2004). The Salinas/Pajaro/Elkhorn complex, referred to here simply as Elkhorn Slough, is the largest estuary on the central coast. Few archaeological sites have been recorded in the Salinas Valley upriver from the estuary and there is little evidence to suggest that its inland fisheries attracted great interest from native people. This situation differs with north-central California where the ethnographic record describes salmon-reliant societies concentrated along river banks. The Elkhorn Slough estuary was a major attraction for prehistoric settlement, but the rivers upstream were not. As such, the current paper focuses only on the open coast and estuarine fisheries and will not deal in detail with the comparatively limited freshwater fisheries. The other substantial bay/estuary environment on the central coast, Morro Bay, is also ringed by prehistoric sites that reflect exploitation of its estuarine/bay fisheries among other things. Unlike Elkhorn Slough, however, Morro
Bay is not connected to any major river. Its sheltered habitats are the product of an extensive sand spit that developed in the late Pleistocene-early Holocene creating a barrier to the open ocean (Masters and Aiello, 2007). There is also good archaeological evidence for at least one major estuary in the vicinity of Pismo Beach/Arroyo Grande that existed during the early and middle Holocene but was covered up by sea level rise over the course of the Holocene (Dills, 1981; Jones et al., 2002). This paleo-estuary is referred to as Halcyon Bay. Other submerged estuaries have been identified further south along the California coast (Erlandson, 1985).

The disappearance of small estuarine systems is an extreme example of changes in fish habitats over time. These systems developed in deeply-incised, Pleistocene river channels that were flooded during post-Last Glacial Maximum (ca. 18,000 years ago) sea level rise (Masters and Aiello, 2007). In general they were deeper and larger during the terminal Pleistocene-early Holocene, but filled with sediments and became smaller and shallower after midHolocene when sea level rise slowed and was out-paced by sediment accumulation. While smaller systems filled and disappeared early, larger estuaries like Morro Bay probably reached its greatest size ca. 5000 years ago as attested by dated estuarine shellfish assemblages (Jones et al., 1994), and decreased in size afterwards due to accumulation of sediment. Adding to the complexity of habitat changes in these systems is variation in sea-surface temperatures along the California coast (Boone, 2012; Jones and Kennett, 1999; Kennett and Kennett, 2000), and shifts in the courses of the Pajaro and Salinas rivers that emptied into Elkhorn Slough. Such changes through time could potentially contribute to variation in fish populations, and stand as yet another alternative explanation for variation in the archaeological record.

Extensive fish habitats in the region are variants of open coast including those with rocky shelves and reefs and intermittent kelp forests, and others fronted by sandy beaches with sandy substrates. These habitats are found along the Big Sur coast of southern Monterey County and the north and central coast of San Luis Obispo County. Exposed rocky shores also front the Monterey Peninsula, but this setting is unique peninsular environment with alternating exposed coast and sheltered coves. Here we treat it as its own separate habitat.

Historically, the primary natural ports that were relied upon by the Spanish to settle the region in the 1700 s and early 1800 s were the sheltered embayments at Avila Beach and Monterey. These locations also have the longest histories of commercial fishing. More recent commercial fishing centers were established at Morro Bay and Elkhorn Slough by the construction of artificial harbors in the 20th century. We employ the historic catch records from Morro Bay as important comparative data to contrast with the prehistoric fish yields.

\subsection{The fishes}

We restrict our consideration here to the fishes that are represented archaeologically. Most of the larger fishes currently present in nearshore waters seem to be represented in shoreline archaeological sites, however, it is not always possible to designate bones to a species especially when the materials are typically well worked, and fragmentary. The archaeologically defined regional fishery includes representatives of the Elasmobranchiomorphi (cartilaginous fishes: sharks, rays, and skates) and the Actinopterygii (ray-finned fishes: all bony fishes excluding the coelacanths, lungfishes, and bichirs) (Table 1). We report at least 15 species of cartilaginous fishes though some are designated only to a family (e.g. Triakidae) or genus (e.g., Raja). At least 87 species of rayfinned fishes have been reported from archaeological sites on the central coast of California. The majority of the fishes are marine, but seven species are exclusively freshwater (four minnows, 


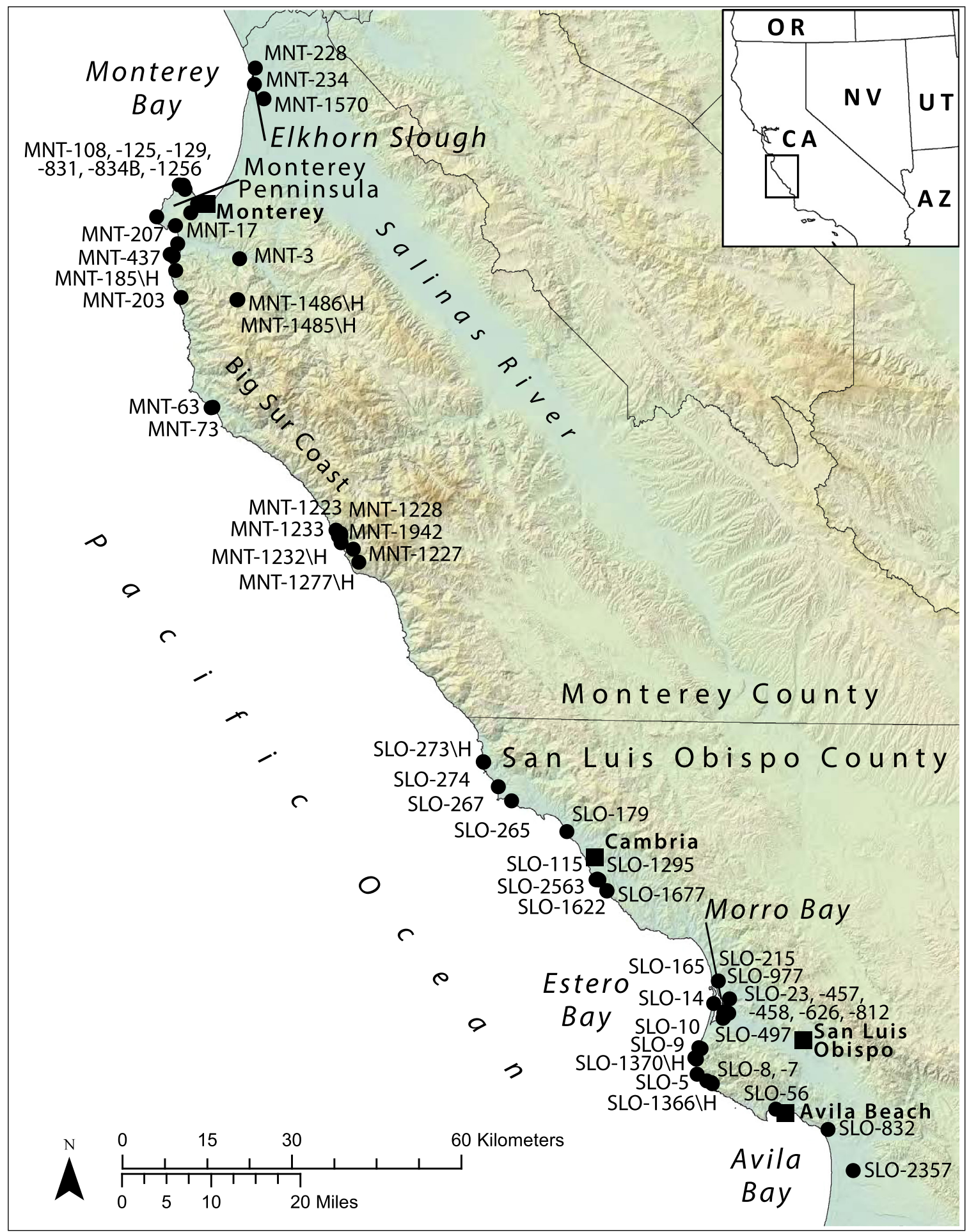

Fig. 2. Study area and sites with temporally controlled fish data.

Sacramento sucker, Sacramento perch, and tule perch) and three are anadromous (sturgeons, Coho salmon, and steelhead rainbow trout). Gobalet et al. (2004) argue that these fishes were probably taken from freshwater streams or estuaries because of the comparative ease of capture. Pacific staghorn sculpin technically marine, but they preferentially inhabit estuaries (Moyle, 2002). The freshwater species are restricted to the Elkhorn Slough estuary, and have not been found at Morro Bay, owing to the isolation of Morro Bay from any major freshwater river.

The fishes are also distinguishable by their size and behavior, attributes that strongly influence their relative accessibility to human fisherman vis-à-vis the technologies most suited to their capture. Most important here is the distinction between medium to large size fish that occur as lone individuals amenable to capture by hook and line, and smaller schooling fishes that could be captured en masse with nets or using baited baskets as described by Fages (1937, see below). Larger flattened fishes that occur in shallow water estuaries would have been susceptible to spears (Pacific angel shark, shovelnose guitarfish, skates, bat ray, flounders, and sole). A number of authors (Boone, 2012; Fitch, 1972; Gause, 2002; Langenwalter and Huddleson, 1991; Love, 2011; Salls, 1988) have described the techniques utilized to capture these 
Table 1

Fishes of the central California coast (terminology and order follow Page et al. (2013)).

\begin{tabular}{|c|c|}
\hline Taxon & Common name \\
\hline Elasmobranchiomorphi & Sharks, skates, and rays \\
\hline Heterodontus francisci & Horn shark \\
\hline Lamnidae & Mackerel sharks \\
\hline Isurus sp. & Mako shark \\
\hline I. oxyrinchus & Shortfin mako \\
\hline Lamna ditropis & Salmon shark \\
\hline Triakidae & Hound sharks \\
\hline Galeorhinus galeus (G. zyopterus) & Tope (soupfin shark) \\
\hline Mustelus californicus & Gray smoothhound \\
\hline M. henlei & Brown smoothhound \\
\hline Triakis semifasciata & Leopard shark \\
\hline Carcharhinidae & Requiem sharks \\
\hline Prionace glauca & Blue shark \\
\hline Squalus acanthias & Spiny dogfish \\
\hline Squatina californica & Pacific angel shark \\
\hline Rhinobatos productus & Shovelnose guitarfish \\
\hline Rajidae & Skates \\
\hline Raja sp. & Skate \\
\hline Platyrhinoidis triseriata & Thornback \\
\hline Urotrygonidae & American round stingrays \\
\hline Myliobatis californica & Bat ray \\
\hline Actinopterygii & Ray-finned fishes \\
\hline Acipenser sp. & White or green sturgeon \\
\hline Engraulis mordax & Northern anchovy \\
\hline Clupeidae & Herrings \\
\hline Clupea pallasii & Pacific herring \\
\hline Sardinops sagax & Pacific sardine \\
\hline Cyprinidae & Carps and minnows \\
\hline Gila crassicauda & Thicktail chub \\
\hline Lavinia exilicauda & Hitch \\
\hline Orthodon microlepidotus & Sacramento blackfish \\
\hline Ptychocheilus grandis & Sacramento pikeminnow (Sacramento squawfish) \\
\hline Catostomus occidentalis & Sacramento sucker \\
\hline Salmonidae & Trouts and salmons \\
\hline Oncorhynchus kistuch & Coho salmon \\
\hline O. mykiss & Rainbow trout, steelhead \\
\hline Osmeridae & Smelts \\
\hline Hypomesus pretiosus & Surf smelt \\
\hline Spirinchus starksi & Night smelt \\
\hline Merluccius productus & Pacific hake \\
\hline Microgadus proximus & Pacific tomcod \\
\hline Chilara taylori & Spotted cusk-eel \\
\hline Porichthys sp. & Midshipman \\
\hline P. notatus & Plainfin midshipman \\
\hline Atherinopsidae & New World silversides \\
\hline Atherinops affinis & Topsmelt \\
\hline Atherinopsis californiensis & Jacksmelt \\
\hline Leuresthes tenuis & California grunion \\
\hline Gasterosteus aculeatus & Threespine stickleback \\
\hline Sebastes spp. & Rockfishes \\
\hline Anoplopoma fimbria & Sablefish \\
\hline Hexagrammos sp. & Greenlings \\
\hline H. decagrammus & Kelp greenling \\
\hline Ophiodon elongatus & Lingcod \\
\hline Cottidae & Sculpins \\
\hline \multicolumn{2}{|l|}{ Clinocottus sp. } \\
\hline C. analis & Mosshead sculpin \\
\hline C. gobiceps & Woolly sculpin \\
\hline \multicolumn{2}{|l|}{ Cottus sp. } \\
\hline Hemilepidotus spinosus & Brown Irish lord \\
\hline \multicolumn{2}{|l|}{ Icelinus sp. } \\
\hline Leptocottus armatus & Pacific staghorn sculpin \\
\hline Scorpaenichthys marmoratus & Cabezon \\
\hline \multicolumn{2}{|l|}{ Paralabrax sp. } \\
\hline Archoplites interruptus & Sacramento perch \\
\hline Seriola lalandi & Yellowtail jack \\
\hline Trachurus symmetricus & Jack mackerel \\
\hline Haemulon californiensis (Xenistius californiensis) & Salema \\
\hline Sciaenidae & Drums and croakers \\
\hline Atractoscion nobilis & White seabass \\
\hline Genyonemus lineatus & White croaker \\
\hline Seriphus politus & Queenfish \\
\hline Girella nigricans & Opaleye \\
\hline
\end{tabular}


Table 1 (continued)

\begin{tabular}{|c|c|}
\hline Taxon & Common name \\
\hline Embiotocidae & Surfperches \\
\hline \multicolumn{2}{|l|}{ Amphisticus sp. } \\
\hline A. rhodoterus & Redtail Surfperch \\
\hline Brachyistius frenatus & Kelp perch \\
\hline Cymatogaster aggregata & Shiner perch \\
\hline Damalichthys vacca (Rhacochilus vacca) & Pile perch \\
\hline Embiotoca jacksoni & Black perch \\
\hline E. lateralis & Striped seaperch \\
\hline Hyperprosopon anale & Spotifin surfperch \\
\hline H. argenteum & Walleye surfperch \\
\hline Hypsurus caryi & Rainbow seaperch \\
\hline Hysterocarpus traskii & Tule perch \\
\hline Micrometrus aurora & Reef perch \\
\hline M. minimus & Dwarf surfperch \\
\hline Phanerodon atripes & Sharpnose seaperch \\
\hline P. furcatus & White seaperch \\
\hline Rhacochilus toxotes & Rubberlip seaperch \\
\hline Chromis punctipinnis & Blacksmith \\
\hline Oxyjulis californica & Señorita \\
\hline Semicossyphus pulcher & California sheephead \\
\hline Stichaeidae & Pricklebacks \\
\hline Anoplarchus purpurescens & High cockscomb \\
\hline Cebidichthys violaceus & Monkeyface prickleback \\
\hline Plagiogrammus hopkinsii & Crisscross prickleback \\
\hline Xiphister atropurpureus & Black prickleback \\
\hline X. mucosus & Rock prickleback \\
\hline Apodichthys flavidus & Penpoint gunnel \\
\hline Anarrhichthys ocellatus ${ }^{\mathrm{a}}$ & Wolf-eel \\
\hline Clinidae & Kelp blennies \\
\hline \multicolumn{2}{|l|}{ Gibbonsia sp. } \\
\hline Gibbonsia metzi & Striped kelpfish \\
\hline Heterostichus rostratus & Giant kelpfish \\
\hline Gobiesox meandricus & Northern clingfish \\
\hline Gobiidae & Gobies \\
\hline Gillichthys mirabilis & Longjaw mudsucker \\
\hline Sphyraena argentea & Pacific barracuda \\
\hline Scombridae & Mackerels \\
\hline Sarda chiliensis & Pacific bonito \\
\hline Scomber japonicus & Pacific chub mackerel \\
\hline Thunnus sp. & Tunas \\
\hline T. alalunga & Albacore \\
\hline Paralichthyidae & Sand flounders \\
\hline Citharichthys sordidus & Pacific sanddab \\
\hline C. stigmaeus & Speckled sanddab \\
\hline Paralichthys californicus & California halibut \\
\hline Pleuronectidae & Righteye flounders \\
\hline Atheresthes stomias & Arrowtooth flounder \\
\hline Eopsetta jordani & Petrale sole \\
\hline Microstomus pacificus & Dover sole \\
\hline Parophrys vetulus (Pleuronectes vetulus) & English sole \\
\hline Platichthys stellatus & Starry flounder \\
\hline Pleuronichthys coenosus & $\mathrm{C}-\mathrm{O}$ sole \\
\hline P. guttulatus (Hypsopsetta guttulata) & Diamond turbot \\
\hline P. ritteri & Spotted turbot \\
\hline Mola mola & Ocean sunfish \\
\hline
\end{tabular}

a Fitch (1972) is the only investigator to report this fish in the archaeological record of California. Recently Gobalet obtained the materials Fitch analyzed and was unable to confirm the presence of Anarrhichthys ocellatus in the samples. These data will be published elsewhere.

fishes based on ethnography and/or the behavioral patterns of the fish. In previous studies (Gobalet and Jones, 1995; Gobalet, 2000; Gobalet et al., 2004) the authors demonstrated that many of the fishes identified were extremely uncommon among individual site or regional assemblages ( $<1 \%$ of the remains) and were unlikely to have been the primary targets of the fishers, but instead may represent incidental stomach contents of larger fish, marine birds, or mammals as suggested by Fitch (1972). More specifically, previous research shows that 25 fishes (or fish clades e.g., Sebastes spp.) account for nearly $90 \%$ of all the fish remains represented in the regional record. In Table 2 we summarize the most likely capture technologies associated with these more common regional fishes.

\subsection{A limited ethnohistory}

When Spanish explorers arrived in AD 1769, most of the central California coast was occupied by a large number of small, autonomous tribal groups that Kroeber (1955) referred to as "tribelets." The manner in which subsistence was accomplished within tribelets vis-à-vis systems of seasonality and settlement is not entirely clear, but the accounts of the earliest Spanish explorers consistently allude to relatively small groups who moved seasonally and exploited a wide range of terrestrial and marine resources. Based on mission records, an estimate of the overall population of the current study area at the time of contact is about 13,000 
Table 2

Most likely capture technologies of select fishes.

\begin{tabular}{|c|c|c|c|c|c|}
\hline By hand & $\begin{array}{l}\text { Hook and line } \\
\text { (including gorge hooks) } \\
\text { nearshore }\end{array}$ & $\begin{array}{l}\text { Hook and line } \\
\text { (w/watercraft) } \\
\text { offshore }\end{array}$ & Spear & $\begin{array}{l}\text { Nearshore net } \\
\text { (mostly small schooling } \\
\text { fishes) }\end{array}$ & $\begin{array}{l}\text { Offshore net (w/watercraft) } \\
\text { (mostly small schooling fishes) }\end{array}$ \\
\hline $\begin{array}{l}\text { Pricklebacks } \\
\text { Plainfin midshipman } \\
\text { Cabezon } \\
\text { Pile perch } \\
\text { Monkeyface prickleback }\end{array}$ & $\begin{array}{l}\text { Bat ray } \\
\text { Plainfin midshipman } \\
\text { Kelp greenling } \\
\text { Lingcod } \\
\text { Pacific staghorn sculpin } \\
\text { Cabezon } \\
\text { Surfperches } \\
\text { Monkeyface prickleback } \\
\text { Pricklebacks } \\
\text { Flounders and soles } \\
\text { Rockfishes }\end{array}$ & $\begin{array}{l}\text { Herrings } \\
\text { Pacific Hake } \\
\text { Rockfishes } \\
\text { Lingcod }\end{array}$ & $\begin{array}{l}\text { Bat ray } \\
\text { Triakid sharks } \\
\text { Plainfin midshipman } \\
\text { Lingcod } \\
\text { Pacific angel shark }\end{array}$ & $\begin{array}{l}\text { Plainfin midshipman } \\
\text { New World silversides } \\
\text { True smelts }\end{array}$ & $\begin{array}{l}\text { Herrings } \\
\text { Northern anchovy }\end{array}$ \\
\hline
\end{tabular}

From Fitch (1972), Salls (1988), Love (2011) and Langenwalter and Huddleson (1991).

individuals (Cook, 1978:91) spread between the shoreline and $100 \mathrm{~km}$ inland.

Fish and fishing are mentioned frequently in the very earliest accounts of encounters between the Spanish and Native central Californians, but these descriptions are woefully lacking in details. The earliest recorded observation by the seafarer, Sebastian Cermeno in 1595, probably in the vicinity of Avila Beach is a good example:

There were observed on the shore of the sea many people on top of some bluffs, where they had many settlements...I anchored in front of these settlements and I saw how the Indians had on shore many balsas made of tule, which are like reeds, or as otherwise called, tule. The balsas were made like canoes, and with these they go fishing. . .shortly one came down from the bluff, and taking a balsa, got into it and came on board the launch, where we made much of him and gave him some pieces of cotton...soon others came and we gave them to understand by signs that they should bring us something to eat, as we had no food...They went ashore and brought some bitter acorns and mush in some dishes made of straw... They use the bow and arrow, and their food consists of bitter acorns and fish.

[Translation by Wagner, 1924:16]

The most detail on fishing was provided by Pedro Fages, who spent four years preparing an official report on the environment and culture of the Native people in south central California. He noted:

... Among the sea fish there are many sea bream, crab, whitefish, curbina [white seabass], sardines of three kinds, cochinillo, and tunny; in the streams and rivers there are trout, spinebacks, machuros, and turtles. The fishing canoes are finely described in the public accounts published in October of the year 1770. The tridents they use are of bone; the barb is well-shaped and well adapted to its use. The fishhooks are made of pieces of shell fashioned with great skill and art. For catching sardines they use large baskets, into which they throw the bait which these fish like, which is the ground up leaves of cactus, so that they come in great numbers; the Indians then make their cast and catch great numbers of sardines.

[Fages, 1937 [1775]:49]

Finally, an important account from the immediately post-contact period suggests highly seasonal (summer) species-specific, targeted fishing in the Monterey Peninsula area:

...After two weeks of fish eating, on the Sunday following, leaving the sardines at peace, they went hunting for the nests of sea birds that live in rocks and feed on fish.
[Serra [1748-1784] quoted in Breschini and Haversat

(1994:184)]

Together the ethnographic accounts document only that fishing was accomplished with hook and line, baskets, trident fish spears, and the tule balsa canoe; we can also assume that nets of some type were employed, but we lack descriptions of this technology. Only a handful of exploited species are mentioned. Ethnographic accounts of Native technology are more complete for the Santa Barbara Channel to the south (Hudson and Blackburn, 1982) but the wide array of maritime implements used by the Island Chumashan speakers was not matched on the central coast mainland where people did not employ the sewn-plank canoe. Some writers have tended to extrapolate the southern technologies to the central coast mainland, but the regional ethnohistory, limited as it is in many ways, makes clear that less complex marine resource technologies dominated north of the islands-with watercraft limited to tule balsa canoes.

\subsection{Archaeological context}

The archaeological record shows that no fewer than 100 species of marine and anadromous fishes were caught prehistorically in this region. Findings from CA-SLO-2 (Jones et al., 2008b) and CASLO-1797 (Jones et al., 2002) show that fishing was undertaken at the earliest sites in the study area which date to ca. $10,000 \mathrm{cal}$ BP. A more recently investigated site, just south of the current study area has also yielded abundant fish remains dating 10,700 cal BP (Lebow et al., 2015). While there are hints of earlier occupations in the region in the form of isolated Clovis projectile points, there are no radiocarbon-dated Clovis sites in the region and the fish bone-bearing middens constitute the earliest substantive evidence for human occupation. The most widely accepted cultural sequence (Jones et al., 2007) divides this prehistory into five prehistoric periods:

\section{Millingstone/Lower Archaic 10,000-5500 cal BP, Early 5500-3000 cal BP ${ }^{1}$, \\ Middle 3000-950 cal BP, \\ Middle/Late Transition 950-700 cal BP, Late 700-200 cal BP.}

The archaeological record provides an important supplement to the poorly detailed ethnographic accounts with the caveat that most of the ethnohistoric fishing implements (hook and line, baskets, spears, tule balsa canoe, and nets) were made of organic

\footnotetext{
${ }^{1}$ Dating of this period reflects revisions to the local cultural chronology suggested
} by Breschini and Haversat (2011). 
materials that do not commonly preserve in this region. The one artifact that links regional ethnohistory with the archaeological record is the circular shell hook (Fig. 3) that has been found at a multitude of sites throughout the region in Late Prehistoric and contact-era contexts. Greenwood's extensive excavations along the Pecho coast in northern Chumash territory show that these hooks came in two forms: J-shaped and C-shaped. Notably, more elaborate grooved and barbed types are limited to the Santa Barbara Channel, and only these simpler forms are known from the central coast. Stratigraphic contexts at Diablo Canyon and directly-dated examples (Breschini and Haversat, 2000) indicate that shell hooks first appeared ca. 3000 cal BP and were used only during the Middle, Middle-Late, and Late periods. This is generally consistent with their dating from the Channel Islands to the south (Rick et al., 2002). Strudwick (1986) who completed an exhaustive study of California shell hooks noted that they are more common on the open coast than along the shores of estuaries. Indeed, many estuarine sites with abundant fish remains have failed to yield a single hook although one example was recovered from Elkhorn Slough (Milliken et al., 1999).

Co-occurring with shell hooks at some open coast sites are notched stones (Fig. 3), (made by chipping notches into the edges of flat cobbles) that seem to have functioned, based on their cooccurrence with hooks, as line sinkers for hook-and-line fishing (Codding et al., 2009; Codding and Jones, 2007). These artifacts are distinguished from grooved stones which exhibit a grooved ring around the circumference of fist-sized stones that are interpreted as net weights although this interpretation is admittedly speculative. Stratigraphic contexts at several sites (CA-MNT-281, -282, CA-SLO-9) show that grooved stones seem to pre-date notched stones in some locations. Fishing technology during the Middle and Late periods seems to have included both nets, marked by grooved-stone net sinkers, and shell hooks. However, some Middle Period sites, especially in estuarine settings (e.g., CAMNT-228, 229), have produced virtually no clear fishing-related artifacts whatsoever despite an abundance of fish bones.

Fishing technologies pre-dating 3000 cal BP are less well understood despite the availability of large excavation samples from a number of sites in San Luis Obispo and Monterey counties. Neither chipped nor grooved stones are known from this time depth, but bone gorges from CA-MNT-108 (Breschini and Haversat, 1989), CA-MNT-391 (Cartier, 1993), and CA-SLO-215 (Jones et al., 2004) indicate that these were among the technologies used in the early and middle Holocene to catch fish in central California. The preponderance of small schooling fishes from pre-3000 cal BP contexts (e.g. from CA-MNT-229 and CA-SLO-165) indicates that nets were employed, and asphaltum-lined cobbles from early and middle Holocene contexts at Morro Bay appear to represent the earliest weights that were attached to nets using this natural tar as an adhesive and sealer.

\section{Study methods}

Since the Gobalet and Jones (1995) study and subsequent update by Gobalet (2000) and Gobalet et al. (2004) we have compiled a database from the published and gray CRM literature of all excavated sites in the central California coastal region with welldelineated, radiocarbon-defined temporal components that produced substantial quantities of fish remains. For the two counties that have yielded the vast majority of fish bones (Monterey and San Luis Obispo), we have information from 86 sites on a total of 202,177 fish remains (Appendix A, Supplementary Table 1) that we have organized by habitat, time, and method of recovery. We also discuss exigencies of varied archaeological methods of fish bone recovery which is a critical consideration in temporal and spatial comparisons (see discussion by Gobalet, 2005).

The majority of the fish remains $(67,256)$ classified to at least Elasmobrachiomorphi (sharks, skates, rays) or a family within the Actinopterygii (ray-finned fishes) were identified by one of us (Gobalet), but the remainder were identified by others. As discussed by Gobalet (2001), relying on studies completed by a single analyst provides for consistency in identification procedures and taxonomic categories. Because analysts vary in these approaches comparing findings from different analysts can be problematic. Changes in nomenclature by taxonomists can also complicate studies that incorporate data collected over a range of time. Nonetheless, a thorough review of the archaeology of fishing requires that we include studies completed by all who have contributed to the record - with the caveat that only reports with sufficiently detailed descriptions of recovery methods and bone identification procedures have been included.

For each site in the database we first determined whether or not radiocarbon dated components were clearly delineated and if faunal data were broken down accordingly. When zooarchaeological studies were first undertaken in California on a regular basis in the 1970s and 1980s it was not uncommon for faunal data to be summarized by site without regard for components. Such studies were generally excluded from the current effort except in the case of sites with single temporal components. For sites with temporally-organized faunal data, we defined the type of methods used to recover the fish remains and further divided component findings by recovery method. With respect to quantifying the actual fish data, findings have been summarized exclusively by Number of Identified Specimens (NISP) rather than by weight. Certainly the relative value of NISP versus weight quantification has been debated (see Glassow, 2000; Mason et al., 1998, 2000), but weight values have not been reported with the same consistency as NISP so only the latter allows us to use more of the regional data for drawing comparisons. For the purposes of the current paper we define "identified" as specimens assigned to at least a family.

Bioturbation has long been recognized as a significant problem in central California where there are substantial populations of ground-burrowing animals including ground squirrels and pocket gophers. From the overall excavation database, only components that showed reasonably coherent cultural chronological integrity, as demonstrated by superimposed radiocarbon dates and agreement with temporally-diagnostic artifacts, as documented in excavation reports, were ultimately included in the fish remains study. Multi-component sites with evidence for extensive mixing were excluded.

The other taphonomic agent that influences bone assemblages in California is soil acidity (Heizer, 1950). Marine shell fragments that constitute a large part of midden contents in coastal sites, however, tend to offset low soil $\mathrm{pH}$ and contribute to favorable preservation environments. Fitch's original (1972) study from Diablo Canyon demonstrated excellent preservation of even the tiniest bones from contexts dating over 9000 years ago. While soil acidity destroys bones in many parts of interior California, this taphonomic variable seems considerably less problematic in the nearshore sites used for the current study.

For each temporal component (and recovery technique) we calculated: (1) total fish NISP; (2) percentage NISP of dominant taxa; (3) density $\left(\mathrm{NISP} / \mathrm{m}^{3}\right.$ ) of identified fish bone as a potential index of the relative importance of fishing; (4) the Margalef Index to evaluate relative richness while controlling for sample size; (5) the Berger-Parker Index (in reciprocal form) to evaluate evenness or relative specialization (Magurran, 1988, 2004). We also assigned size class and technological category to each component based on the dominant fish. Size classes are based on the maximum weight of the dominant species ranging from small $(<1 \mathrm{~kg})$, 


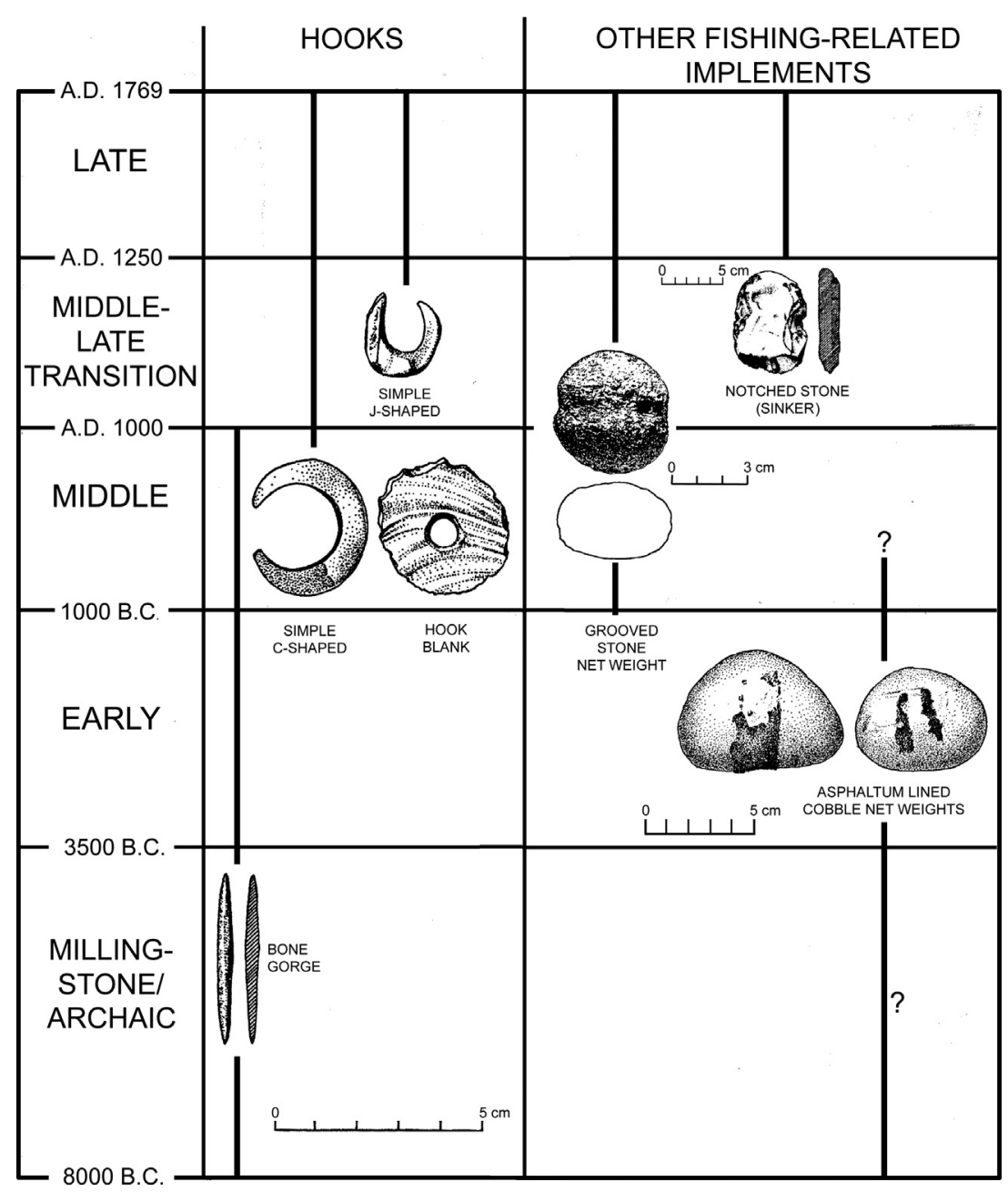

Fig. 3. Chronology of prehistoric fishing equipment on the central California coast.

medium (1-2 kg) to large ( $>2 \mathrm{~kg}$ ). Technological categories are estimates derived from the limited ethnographic data (see Codding and Jones, 2007) and aggregated into two categories: mass capture (e.g., nets) vs. individual capture (e.g., hook and line, spears). Components were aggregated according to local fish habitats, and patterns over time were evaluated. Assignments to temporal components were based on radiocarbon dates corrected for isotopic fractionation and calibrated with a local upwelling correction value of $290 \pm 35$ (Ingram and Southon, 1996).

\subsection{Recovery techniques}

The revolution in American archaeology that began over 40 years ago brought with it a concern that large mesh apertures (1/4 in. or $6 \mathrm{~mm}$ ) were inadequate for recovery of small materials like fish bones, and that the relative importance of resources like fish, shellfish, small birds and mammals could be misinterpreted by exclusive reliance of large mesh (Casteel, 1972; Thomas, 1969). Certainly there can be no denying the basic logic underlying this concern which has been expressed repeatedly in the intervening decades (Gordon, 1993; James, 1997; Schaffer and Sanchez, 1994; Stahl, 1996; Zohar and Belmaker, 2005). In response to this methodological issue, California archaeologists have increasingly emphasized smaller mesh when sampling coastal midden deposits, but there remains no consensus on the ideal mesh size, excavation volume, or processing technique. The reports included in the present data base detail sampling strategies in which three alter- native mesh sizes were employed: $6 \mathrm{~mm}$ (1/4 in.), $3 \mathrm{~mm}$ ( $1 / 8 \mathrm{in}$.), and $1.5 \mathrm{~mm}(1 / 16 \mathrm{in}$.) in concert with one of two basic processing techniques: one in which recovered residues were sorted dry in the field by excavation technicians (dry-screening) and another in which materials recovered from the field were transported to the laboratory, washed, and sorted (wet-screening).

Many investigations have employed only a single method of recovery, but sites where more than one method was employed allow for comparisons of relative rates of fish bone recovery (Table 3). Such comparisons show clear trends: (1) the smaller the mesh, the more fish bone recovered, (2) water-screening with laboratory sorting produces more bones than dry-screening, and (3) smaller mesh shows greater frequencies of species that attain only modest size. The difference between wet-screening and dryscreening is perhaps the most significant as the former method has consistently produced samples up to one-two orders of magnitude larger than the latter. Species trends, however, are less straight-forward. In most cases, $1 / 8$-in. and 1/16-in. wetscreened samples show different dominant species. For example, $1 / 8$-in. dry-screened residues from CA-MNT-3 were dominated by rockfish, but $1 / 8$-in. and $1 / 16$-in. wet-screened residues showed a prevalence of the smaller herrings. However, 1/8-in. dryscreened and wet-screened samples from CA-SLO-9 are both dominated by rockfish showing that the correlation between mesh size and taxonomic variation is neither simple nor wholly predictable. A study by Jones and Codding (2012) showed that smaller screen samples generally produce greater species diversity, but they also 
Table 3

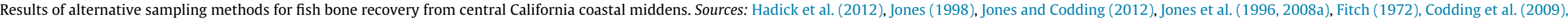
Mikkelsen et al. (2000), Jones et al. (1994), Jones and Waugh (1995), Jones and Ferneau (2002), Hildebrandt et al. (2002) and Joslin (2006),

\begin{tabular}{|c|c|c|c|c|c|c|c|c|c|c|c|c|c|c|c|c|}
\hline \multirow[t]{2}{*}{ Site } & \multicolumn{4}{|c|}{$\begin{array}{l}6 \mathrm{~mm}(1 / 4 \mathrm{in} .) \\
\text { dry recovery }\end{array}$} & \multicolumn{4}{|c|}{$3 \mathrm{~mm}$ (1/8 in.) dry recovery } & \multicolumn{4}{|c|}{$3 \mathrm{~mm}$ (1/8 in.) wet recovery } & \multicolumn{4}{|c|}{$1.5 \mathrm{~mm}$ (1/16th in.) wet recovery } \\
\hline & $\begin{array}{l}\text { Excavation } \\
\text { volume } \\
\left(\mathrm{m}^{3}\right)\end{array}$ & NISP & $\mathrm{NISP} / \mathrm{m}^{3}$ & $\begin{array}{l}\text { Dominant } \\
\text { fish group } \\
(\%)\end{array}$ & $\begin{array}{l}\text { Excavation } \\
\text { volume }\left(\mathrm{m}^{3}\right)\end{array}$ & NISP & $\mathrm{NISP} / \mathrm{m}^{3}$ & $\begin{array}{l}\text { Dominant } \\
\text { fish group (\%) }\end{array}$ & $\begin{array}{l}\text { Excavation } \\
\text { volume }\left(\mathrm{m}^{3}\right)\end{array}$ & NISP & $\mathrm{NISP} / \mathrm{m}^{3}$ & $\begin{array}{l}\text { Dominant } \\
\text { fish group (\%) }\end{array}$ & $\begin{array}{l}\text { Excavation } \\
\text { volume }\left(\mathrm{m}^{3}\right)\end{array}$ & NISP & $\mathrm{NISP} / \mathrm{m}^{3}$ & $\begin{array}{l}\text { Dominant } \\
\text { fish group (\%) }\end{array}$ \\
\hline CA-MNT-3 & - & - & - & - & $9.8^{\mathrm{a}}$ & 19 & 2 & Rockfishes (26.3) & $0.088^{\mathrm{b}}$ & 75 & 852 & Herrings (72.4) & $0.088^{\mathrm{b}}$ & 173 & 1948 & Herrings (80.3) \\
\hline CA-MNT-228 & $10.7^{\mathrm{a}}$ & 20 & 2 & - & $20.6^{\mathrm{a}}$ & 39 & 2 & - & 1.900 & 3463 & 1822 & Silversides (34.6) & .0200 & 321 & 16,050 & Silversides (39.8) \\
\hline CA-SLO-2 & $109^{\mathrm{a}}$ & 6070 & 57 & Cabezon (35.9) & - & - & - & - & - & - & - & - & $0.800^{\mathrm{a}}$ & 1331 & 1663 & Surfperches (35.5) \\
\hline CA-SLO-5 & - & - & - & - & 8.6 & 22 & 2.5 & Cabezon (50.0) & 1.8 & 604 & 335.6 & Herrings (27.8) & - & - & - & - \\
\hline CA-SLO-9 & $1.8^{\mathrm{a}}$ & 34 & 22 & Cabezon (58.8) & $30.4^{\mathrm{a}}$ & 516 & 17 & Rockfishes (47.7) & $2.000^{\mathrm{a}}$ & 205 & 103 & Rockfishes (32.2) & - & - & - & - \\
\hline CA-SLO-56 & $0.3^{\mathrm{a}}$ & 16 & 53 & $\begin{array}{l}\text { Rockfishes } \\
\text { (56.3) }\end{array}$ & $5.0^{\mathrm{a}}$ & 185 & 37 & Herrings (30.3) & - & - & - & - & $0.08^{\mathrm{a}}$ & 100 & 1250 & Herrings (64) \\
\hline CA-SLO-71 & - & - & - & - & - & - & - & - & $1.27^{\mathrm{b}}$ & 1911 & 1504.7 & $\begin{array}{l}\text { Pricklebacks } \\
\text { (35.5) }\end{array}$ & $0.068^{\mathrm{b}}$ & 179 & 2632.4 & $\begin{array}{l}\text { Pricklebacks } \\
\text { (44.7) }\end{array}$ \\
\hline CA-SLO-165 & - & - & - & - & $41.1^{\mathrm{a}}$ & 712 & 17 & & - & - & - & & $1.600^{\mathrm{a}}$ & 1484 & 928 & \\
\hline CA-SLO-175 & $5.8^{\mathrm{a}}$ & 15 & 3 & Cabezon (26.6) & - & - & - & - & - & - & - & - & $0.027^{\mathrm{a}}$ & 355 & 13,148 & Herrings (48.2) \\
\hline CA-SLO-179 & $1.3^{\mathrm{b}}$ & 155 & 119 & $\begin{array}{l}\text { Rockfishes } \\
\text { (58.1) }\end{array}$ & $8.2^{\mathrm{a}}$ & 2812 & 343 & Herrings (31.3) & $1.300^{\mathrm{b}}$ & 1621 & 1247 & Herrings (32.0) & $1.300^{\mathrm{b}}$ & 3570 & 2746 & Herrings (33.3) \\
\hline CA-SLO-273/H & $2.3^{\mathrm{a}}$ & 5 & 11 & & 0 & 0 & - & & $1.800^{\mathrm{b}}$ & 53 & 29 & & $0.064^{\mathrm{b}}$ & 70 & 1093 & \\
\hline CA-SLO-274 & $2.1^{\mathrm{a}}$ & 10 & 5 & & 0 & 0 & - & & $1.600^{\mathrm{b}}$ & 178 & 111 & & $0.068^{b}$ & 151 & 2220 & \\
\hline CA-SLO-267 & $0.8^{\mathrm{b}}$ & 66 & 83 & $\begin{array}{l}\text { Rockfishes } \\
\text { (36.4) }\end{array}$ & $7.0^{\mathrm{a}}$ & 23 & 3 & Surfperches (43.5) & $0.800^{\mathrm{b}}$ & 225 & 281 & Rockfishes (32.0) & $0.800^{\mathrm{b}}$ & 367 & 459 & $\begin{array}{l}\text { Pricklebacks } \\
(25.6)\end{array}$ \\
\hline $\begin{array}{r}\text { CA-SLO-1370/H } \\
\text { component } 2\end{array}$ & - & - & - & - & $8.0^{\mathrm{a}}$ & 109 & 13.6 & Rockfishes (40.4) & $0.800^{\mathrm{a}}$ & 51 & 64 & Rockfishes (37.3) & - & - & - & - \\
\hline
\end{tabular}

${ }^{\text {a }}$ Samples sifted through nested screens of different mesh

b Sample of different mesh obtained from different excavation units at the same site. 
found that relative trends through time in diversity were identical regardless of screen size from which they concluded that the most important precaution to be taken in evaluating fish remains from multiple sites is to hold methods constant and only compare (methodologically) like samples with like. We follow this procedure here.

\subsection{Categories of identification}

An important study by Gobalet (2001) in which four different analysts identified and quantified the same set of fish remains showed variation associated with different analysts and their approaches to classification. Most apparent in this study was the willingness of some analysts to identify elements to a species while others were only confident with identification to a genus or family. To avoid this problem for the current study, all identifications were collapsed into the taxonomic categories listed in Table 1 which, are those for which Gobalet has the most confidence in his analyses spanning 40 years. This is not to imply that Gobalet's identifications are necessarily more accurate than those of others, but quantified comparisons can only be completed when all specimens have been assigned to the same taxonomic categories. ${ }^{2}$

Also important in the completion of identifications is for analysts to have at their disposal extensive skeletal reference collections. For the current paper we have only accepted findings from researchers who identified the reference collection used in their analyses. Most of the remains in this study were identified by one of us (Gobalet) who used the reference collection housed at the Department of Biology, California State University, Bakersfield. ${ }^{3}$

\subsection{Statistical evaluation}

We rely on a number of simple statistics to assess the significance of synchronic and diachronic trends. Analyses examining variation in counts (e.g., the number of components) rely on $\chi^{2}$ tests and report the $\chi^{2}$ statistic, degrees of freedom (df) and the alpha (or $p$ ) value. Analyses examining continuous (e.g., fish bone density) or proportional (e.g., 1/Berger-Parker Index) data rely on non-parametric, rank-ordered tests because the dependent variables are not expected to be normally distributed. To determine if continuous measures vary significantly across categories (e.g., fish bone density across habitats), we run Kruskal-Wallis ranksums tests, reporting on the $\chi^{2}$ statistic, df and $p$-value. To determine if median differences in linear diachronic trends are significant, we rely on Kendall's $\tau$, reporting the $\tau$ statistic and $p$-value. All analyses are run in the $\mathrm{R}$ environment ( $\mathrm{R}$ Core Development Team, 2014).

\subsection{Modern fishery records}

For the purpose of comparison we acquired catch records for the Port of Morro Bay in San Luis Obispo County kept by the California Department of Fish and Game $(1976,2010)$ for the period from 1947 to 2010. Commercial fishing began at this port in 1947 after a breakwater was constructed. The records represents catches made by commercial fishing vessels that employed large commercial nets and were capable of collecting fish from 100 miles or more in all directions from the port.

\footnotetext{
2 Since we use only common names in this text the reader is referred to Table 1 that follows the most recent standard of the American Fisheries Society (Page et al., 2013).

3 This collection was recently donated to the Icthyology Department, California Academy of Science, San Francisco.
}

\section{Results}

From the total of 86 excavated sites in the database, 57 provided a total of 79 reasonably cohesive temporal components with accurate dating and proper reporting for a total of 75,532 NISP. Forty-two components were processed by dry-screening (Table 4) and 37 were wet-screened (Table 5). The dry-screened materials were from two habitats: the exposed rocky coast and the southern bay/estuaries (Morro Bay and Halcyon Bay). The wet-screened residues represent the exposed rocky coast, the Monterey Peninsula, and the northern bay/estuary at Elkhorn Slough. Findings from Elkhorn Slough are of somewhat limited value for diachronic comparison because no substantive components post-dating $950 \mathrm{cal} \mathrm{BP}$ have been identified there. Components in the sample also vary numerically across time in the region with a significant increase in the Early Period $(n=22)$ over the Millingstone/Lower Archaic Period ( $n=11$; Table $\left.6 ; \chi^{2}=3.67, \mathrm{df}=1, p=0.0555\right)$ which has been interpreted previously as evidence for a regional population increase at that time ( $c f$ Jones, 1992, 1996; Mikkelsen et al., 2000; see also Codding et al., 2012; Jones et al., 2007).

\subsection{Overarching synchronic trends}

Fish bone density recovered from wet-screened components varies meaningfully across habitats $\left(\chi^{2}=5.62, \mathrm{df}=2, \quad p\right.$ value $=0.0608)$, but not across dry-screened components $\left(\chi^{2}=0.44, \mathrm{df}=2, p=0.5\right)$. The greatest density of fish remains $\left(\mathrm{NISP} / \mathrm{m}^{3}\right)$ is represented by findings from the wet-screen residues from the Elkhorn Slough bay/estuary (mean $=4505$ ) and the Monterey Peninsula ( mean $=934$ ) with one component from the former yielding over 20,000 elements $/ \mathrm{m}^{3}$ (Breschini and Haversat, 1995). The exposed rocky coast shows more modest yields: mean $=72$ for dry-screened residues and 198 for wet-screened.

Assemblage diversity (Margalef's Index) varies significantly across habitats for the wet- $\left(\chi^{2}=12.69, \mathrm{df}=2, p=0.0018\right)$ and dry-screened samples $\left(\chi^{2}=12.54, \mathrm{df}=2, p=0.0003\right)$. The greatest assemblage diversity (3.76) comes from the southern estuaries of Morro and Halcyon bays. These high diversity scores probably reflect the concentration of multiple neighboring habitats (estuary, open sandy, and open rocky shores) and the heavy emphasis on smaller (Fig. 4a) netted fish (Fig. 4b). The dominant fish groups acquired vary significantly in size class and technology across habitats for both the wet-screened $\left(\chi^{2}=18.47, \mathrm{df}=4, p=0.0010\right.$ and $\chi^{2}=8.94, \quad \mathrm{df}=2, \quad p<0.0115$ respectively) and dry-screened $\left(\chi^{2}=22.1888, \mathrm{df}=2, p<0.0001\right.$ and $\chi^{2}=19.79, \mathrm{df}=1, p<0.0001$ respectively) samples. This suggests that fishing profitability varied significantly across habitats.

Combining samples from both recovery techniques, the total temporally controlled sample of 75,532 NISP is dominated by six fish groups: herrings (NISP $=30,195 ; 39.9 \%$ ), surfperches $(\mathrm{NISP}=11,376 ; 15.1 \%)$, New World silversides $\quad(\mathrm{NISP}=8773$; $11.6 \%)$, rockfishes (NISP $=7018 ; 9.3 \%)$, cabezon $(\mathrm{NISP}=1751$; $2.3 \%$ ), and pricklebacks (NISP $=907 ; 1.2 \%$; (Appendix A, Supplementary Tables 2-11). Additionally, a large number (NISP = 4406) of flounder or sole bones was recovered from one site (CA-MNT234 at Elkhorn Slough), but these flatfishes were otherwise unimportant in the study area.

\subsubsection{Exposed rocky coast}

Thirty-seven components represent the exposed rocky coast, 25 were dry-screened, and 12 were wet-screened. Irrespective of time or recovery method, these components are significantly biased $\left(\chi^{2}=24.1176, \mathrm{df}=3, p<0.0001\right)$ toward the dominance of by rockfish (20 components) and cabezon (9 components) (Appendix A, 
Table 4

Fish remains from temporal components processed with $1 / 8$ in. mesh dry.

\begin{tabular}{|c|c|c|c|c|c|c|c|c|c|c|}
\hline \multirow[t]{2}{*}{ Trinomial } & \multicolumn{3}{|c|}{ Temporal component } & \multicolumn{3}{|l|}{ Dominant fish group } & \multirow{2}{*}{$\begin{array}{l}\mathrm{NISP} / \mathrm{m}^{3} / \\
\text { component }\end{array}$} & \multirow[t]{2}{*}{ No. species } & \multirow{2}{*}{$\begin{array}{l}\text { Margalef } \\
\text { index }\end{array}$} & \multirow{2}{*}{$\begin{array}{l}\text { Recip Berger- } \\
\text { Parker Index }\end{array}$} \\
\hline & Period & $\begin{array}{l}\text { Exca. } \\
\text { volume }\left(\mathrm{M}^{3}\right)\end{array}$ & NISP & Name & $\mathrm{N}$ & $\%$ & & & & \\
\hline \multicolumn{11}{|c|}{ Exposed rocky coast, San Luis Obispo County, Big Sur (Monterey County) } \\
\hline MNT-1223 & Late & 13.40 & 129 & Rockfishes & 94 & 72.9 & 9.6 & 7 & 1.234 & 1.655 \\
\hline MNT-1227 & Late & 3.80 & 295 & Rockfishes & 174 & 58.9 & 77.6 & 10 & 1.402 & 2.040 \\
\hline MNT-1277/H & Late/Historic & 5.00 & 166 & Rockfishes & 113 & 68.1 & 33.0 & 7 & 1.176 & 1.474 \\
\hline MNT-1942 & Late & 8.20 & 277 & Rockfishes & 168 & 60.6 & 33.2 & 13 & 2.342 & 1.650 \\
\hline SLO-1366/H & Late & 1.20 & 27 & Rockfishes & 10 & 37.0 & 22.5 & 8 & 2.124 & 2.702 \\
\hline Subtotal & & 31.6 & 894 & & & & 28.3 & & & \\
\hline MNT-1233 & M-L & 3.40 & 425 & Rockfishes & 303 & 71.3 & 125.0 & 8 & & \\
\hline SLO-9 & M-L & 32.20 & 516 & Rockfishes & 246 & 47.7 & 16.0 & 18 & 2.721 & 2.100 \\
\hline SLO-179 & M-L & 8.20 & 2550 & Herrings & 880 & 34.5 & 310.9 & 34 & 4.207 & 2.898 \\
\hline SLO-2563 & M-L & 0.70 & 195 & Pricklebacks & 75 & 38.5 & 278.6 & 18 & 3.224 & 2.604 \\
\hline Subtotal & & 44.5 & 3686 & & & & 82.8 & & & \\
\hline MNT-63 & Middle & 4.60 & 584 & Rockfishes & 299 & 51.2 & 126.9 & 14 & 2.041 & 1.956 \\
\hline SLO-5 & Middle & 8.64 & 22 & Cabezon & 11 & 50.0 & 2.5 & 5 & 1.515 & 0.500 \\
\hline SLO-10 & Middle & 10.80 & 1618 & Rockfishes & 710 & 43.9 & 149.8 & 26 & 3.393 & 2.247 \\
\hline SLO-267 & Middle & 7.00 & 23 & Surfperches & 10 & 43.5 & 3.3 & 5 & 1.275 & 2.304 \\
\hline Subtotal & & 31.04 & 2247 & & & & 72.4 & & & \\
\hline MNT-73 & Early & 20.9 & 261 & Cabezon & 102 & 39.1 & 12.5 & 7 & 5.564 & 2.564 \\
\hline MNT-1228 & Early & 22.00 & 10 & Cabezon & 7 & 70.0 & 0.5 & 3 & 0.434 & 1.428 \\
\hline MNT-1232/H & Early & 1.80 & 36 & Cabezon & 15 & 41.7 & 20.0 & 6 & 1.395 & 2.403 \\
\hline SLO-265 & Early & 2.10 & 90 & Surfperches & 25 & 27.8 & 42.9 & 14 & 2.947 & 3.332 \\
\hline SLO-497 & Early & 2.30 & 47 & Rockfishes & 23 & 48.9 & 20.4 & 6 & 1.298 & 2.044 \\
\hline \multirow[t]{3}{*}{ SLO-1295 } & Early & 1.07 & 14 & Cabezon & 4 & 28.6 & 13.1 & 5 & 1.481 & 3.759 \\
\hline & & & & Pricklebacks & 4 & & & & & \\
\hline & & & & Kelp Greenling & 4 & & & & & \\
\hline SLO-1366/H & Early & 6.40 & 39 & Rockfishes & 20 & 51.3 & 6.1 & 6 & 1.846 & 1.953 \\
\hline SLO-1370/H & Early & 8.00 & 109 & Rockfishes & 44 & 40.4 & 13.6 & 19 & 3.837 & 2.481 \\
\hline SLO-1622 & Early & 0.75 & 92 & Pricklebacks & 27 & 29.3 & 122.6 & 11 & 2.211 & 3.412 \\
\hline SLO-1677 & Early & 1.50 & 299 & Pricklebacks & 143 & 47.8 & 199.3 & 14 & 2.280 & 2.092 \\
\hline Subtotal & & 66.82 & 997 & & & & 14.9 & & & \\
\hline MNT-1232/H & Milling & 2.40 & 39 & Cabezon & 19 & 48.7 & 16.3 & 8 & 1.911 & 2.053 \\
\hline SLO-10 & Milling & 2.10 & 138 & Rockfishes & 74 & 53.6 & 65.7 & 16 & 3.044 & 1.972 \\
\hline Subtotal & & 4.50 & 177 & & & & 39 & & & \\
\hline Open Coast Subtotals & & 178.46 & 8001 & & & & 44.8 & & & \\
\hline \multicolumn{11}{|c|}{ Estuary (Morro Bay and Halcyon Bay) } \\
\hline SLO-23 & Late & 14.08 & 4231 & Surfperches & 1680 & 39.7 & 300.5 & 40 & 4.670 & 2.518 \\
\hline SLO-626 & Late & 11.70 & 858 & Surfperches & 351 & 40.9 & 73.3 & 33 & 4.737 & 2.444 \\
\hline Subtotal & & 25.78 & 5089 & & & & 197 & & & \\
\hline SLO-457 & M-L & 5.20 & 7188 & Surfperches & 4161 & 57.9 & 1382.3 & 40 & 4.391 & 1.730 \\
\hline Subtotal & & 5.20 & 7188 & & & & 1382.3 & & & \\
\hline SLO-14 & Middle & 21.40 & 2430 & Silversides & 989 & 40.7 & 113.6 & 38 & 4.749 & 2.463 \\
\hline SL0-56 & Middle & 5.00 & 185 & Herrings & 56 & 30.3 & 37.0 & 26 & 4.789 & 3.134 \\
\hline SLO-165 & Middle & 1.20 & 25 & Surfperches & 8 & 32.0 & 20.8 & 8 & 2.175 & \\
\hline SLO-812 & Middle & 3.94 & 123 & Silversides & 25 & 20.3 & 31.2 & 14 & 4.812 & 4.926 \\
\hline Subtotal & & 31.54 & 2763 & & & & 88 & & & \\
\hline SLO-23 & Early & 27.56 & 3129 & Surfperches & 1259 & 40.2 & 113.5 & 43 & 5.218 & 2.487 \\
\hline SLO-165 & Early & 37.20 & 620 & Surfperches & 169 & 27.3 & 16.7 & 29 & 4.044 & 3.676 \\
\hline SLO-458 & Early & 9.30 & 32 & Silversides & 12 & 37.5 & 3.44 & 8 & 2.023 & 2.666 \\
\hline SLO-812 & Early & 2.40 & 162 & Surfperches & 51 & 31.5 & 67.5 & 13 & 2.527 & 3.184 \\
\hline SLO-977 & Early & 1.00 & 226 & Pacific staghorn sculpin & 55 & 24.3 & 226 & 18 & 3.136 & 4.115 \\
\hline Subtotal & & 77.46 & 4169 & & & & 54 & & & \\
\hline SLO-0165 & Milling & 3.50 & 404 & Silversides & 197 & 48.8 & 115.4 & 16 & 3.568 & 3.952 \\
\hline SLO-215 & Milling & 4.40 & 645 & Surfperches & 406 & 62.9 & 146.6 & 29 & 4.331 & 1.594 \\
\hline SLO-812 & Milling & 4.80 & 131 & Herrings & 29 & 25.0 & 24.2 & 16 & 3.073 & 4.566 \\
\hline SLO-832 & Milling & 8.15 & 78 & Surfperches & 31 & 39.7 & 9.6 & 12 & 2.525 & 2.518 \\
\hline SLO-2357 & Milling & 2.86 & 33 & Surfperches & 10 & 30.3 & 4.90 & 10 & & \\
\hline Subtotal & & 23.71 & 1276 & & & & 39 & & & \\
\hline Estuarine subtotal & & 163.69 & 20,500 & & & & 125.2 & & & \\
\hline
\end{tabular}

Supplementary Tables 2-11). Both of these fishes are generally associated with hook and line fishing. The prickleback and surfperch families dominate three and two components respectively. The former includes species that can actually be collected by hand from the intertidal while the latter include a large number of species amenable to capture by both hook and net. Surfperches are the only category of fishes that was taken in substantial numbers from both the open coast and estuaries. The surfperch family, Embiotocidae, contains 18 species that can be found in predictable marine habitats (e.g., sandy, rocky reef, kelp, etc.; Love, 2011).

\subsubsection{Monterey Peninsula}

While some dry-screened components have been reported from the Monterey Peninsula they are too few and were reported so long ago that we have considered only more recent and robust wetscreened samples here. The sample includes 18 temporal components although only one (CA-MNT-17) pre-dates 5500 cal BP. Patterns over time are also complicated by inter-analyst variation in identifications, specifically of herrings and sardines. One analyst has been more confident in assigning elements to a species, Pacific sardine while others have generally limited identification to the 
Table 5

Fish remains from temporal components processed with $1 / 8$ in. mesh and water.

\begin{tabular}{|c|c|c|c|c|c|c|c|c|c|c|}
\hline \multirow[t]{2}{*}{ Trinomial } & \multicolumn{3}{|c|}{ Temporal component } & \multicolumn{3}{|l|}{ Dominant fish group } & \multirow{2}{*}{$\begin{array}{l}\mathrm{NISP} / \mathrm{m}^{3} / \\
\text { component }\end{array}$} & \multirow{2}{*}{$\begin{array}{l}\text { No. } \\
\text { species }\end{array}$} & \multirow{2}{*}{$\begin{array}{l}\text { Margalef } \\
\text { index }\end{array}$} & \multirow{2}{*}{$\begin{array}{l}\text { Recip Berger- } \\
\text { Parker Index }\end{array}$} \\
\hline & Period & $\begin{array}{l}\text { Exca. } \\
\text { volume }\left(\mathrm{M}^{3}\right)\end{array}$ & NISP & Name & $\mathrm{N}$ & $\%$ & & & & \\
\hline \multicolumn{11}{|c|}{ Exposed Rocky Coast, San Luis Obispo County and Big Sur } \\
\hline SLO-7 & Late & 5.60 & 1230 & Rockfishes & 700 & 56.9 & 219.6 & 15 & 1.967 & 1.757 \\
\hline SLO-8 & Late & 1.30 & 104 & Rockfishes & 46 & 44.2 & 80.0 & 10 & 1.939 & 2.262 \\
\hline SLO-115 & Late & 1.00 & 41 & Rockfishes & 16 & 39.0 & 41.0 & 4 & 0.807 & 2.564 \\
\hline Subtotal & & 7.9 & 1375 & & & & 175 & & & \\
\hline SLO-9 & $\mathrm{M}-\mathrm{L}$ & 2.06 & 205 & Rockfishes & 66 & 32.2 & 99.5 & 14 & 2.442 & 3.115 \\
\hline SLO-273/H & $\mathrm{M}-\mathrm{L}$ & 0.80 & 43 & Cabezon Rockfishes & 13 & 30.2 & 53.8 & 9 & 2.127 & 3.311 \\
\hline SLO-179 & $\mathrm{M}-\mathrm{L}^{\mathrm{a}}$ & 1.30 & 1621 & Herrings & 519 & 32.0 & 1246.9 & 30 & 3.978 & 2.824 \\
\hline Subtotal & & 4.16 & 1869 & & & & 449.3 & & & \\
\hline MNT-185/H & Middle & 3.20 & 46 & Rockfishes & 36 & 78.3 & 14.38 & 4 & 0.783 & 1.278 \\
\hline SLO-5 & Middle & 1.80 & 604 & Herrings & 168 & 27.8 & 335.5 & 16 & 2.342 & 3.597 \\
\hline SLO-267 & Middle & 0.80 & 225 & Rockfishes & 72 & 32.0 & 281 & 13 & 2.215 & 3.125 \\
\hline Subtotal & & 5.8 & 875 & & & & 151 & & & \\
\hline SLO-273/H & Early & 1.00 & 10 & Cabezon & 5 & 50.0 & 10.0 & 3 & 0.868 & 2.000 \\
\hline SLO-274 & Early & 1.60 & 178 & Cabezon & 82 & 46.1 & 111.3 & 12 & 2.123 & 4.132 \\
\hline SLO-1366/H & Early & 1.00 & 22 & Rockfishes & 8 & 38.1 & 22.0 & 7 & 1.941 & 2.754 \\
\hline SLO-1370/H & Early & 0.80 & 51 & Rockfishes & 19 & 37.3 & 63.7 & 13 & 3.052 & 2.688 \\
\hline Subtotal & & 4.4 & 261 & & & & 59 & & & \\
\hline Open Coast Subtotals & & 20.2 & 4380 & & & & 216.8 & & & \\
\hline \multicolumn{11}{|l|}{ Monterey Peninsula } \\
\hline MNT-17 & Late & - & 146 & Herrings & 41 & 28.1 & & 12 & 2.207 & 3.571 \\
\hline MNT-129 & Late & 1.40 & 443 & Rockfishes & 255 & 57.6 & 316.4 & 19 & 2.954 & 1.718 \\
\hline MNT-125 & Late & 1.80 & 14 & Cabezon Pricklebacks & 6 & 42.9 & 7.8 & 4 & 1.136 & 2.336 \\
\hline MNT-1256 & Late & 0.60 & 485 & Herrings & 235 & 48.5 & 808 & 16 & 2.425 & 2.066 \\
\hline MNT-1485/H & Late & 7.20 & 12,788 & Herrings & 12474 & 97.5 & 1776.1 & 17 & 1.696 & 1.027 \\
\hline MNT-1486/H & Late & 11.6 & 8668 & Herrings & 8538 & 98.5 & 747.2 & 13 & 1.324 & 1.015 \\
\hline Subtotal & & 22.6 & 22,544 & & & & 998 & & & \\
\hline MNT-3 & $\mathrm{M}-\mathrm{L}$ & 0.09 & 75 & Herrings & 68 & 72.4 & 852 & 7 & 1.389 & 1.103 \\
\hline MNT-152 & $\mathrm{M}-\mathrm{L}$ & 2.10 & 38 & Surfperches & 12 & 31.6 & 18.1 & 7 & 0.274 & 3.174 \\
\hline MNT-203 & M-L & 0.03 & 55 & Rockfishes & 23 & 41.8 & 2200 & 8 & 1.746 & 2.392 \\
\hline MNT-834B & $\mathrm{M}-\mathrm{L}$ & 2.40 & 229 & Surfperches & 69 & 30.1 & 95.4 & 12 & 2.024 & 3.322 \\
\hline Subtotal & & 4.62 & 397 & & & & 86 & & & \\
\hline MNT-207 & Middle & 0.97 & 256 & Rockfishes & 93 & 36.3 & 263.9 & 16 & 2.705 & 2.754 \\
\hline MNT-437 & Middle & 0.03 & 22 & Herrings & 18 & 81.8 & 785.7 & 3 & 0.647 & 1.222 \\
\hline MNT-831 & Middle & 3.25 & 109 & Rockfishes & 35 & 32.1 & 33.5 & 12 & 2.344 & 3.115 \\
\hline Subtotal & & 4.25 & 387 & & & & 91 & & & \\
\hline MNT-17 & Early & - & 780 & Rockfishes & 361 & 46.3 & - & 20 & 0.947 & 2.164 \\
\hline MNT-108 & Early & 0.5 & 3006 & Herrings & 1825 & 60.7 & 6012 & 16 & 1.873 & 1.647 \\
\hline MNT-831 & Early & 4.2 & 212 & Rockfishes & 78 & 36.8 & 50.5 & 11 & 1.867 & 2.724 \\
\hline MNT-1256 & Early & 0.6 & 23 & Rockfishes & 12 & 52.2 & 38.3 & 7 & 1.913 & 1.919 \\
\hline Subtotal & & 5.3 & 4021 & & & & 759 & & & \\
\hline MNT-17 & Milling & - & 229 & Herrings & 138 & 60.3 & - & 12 & 2.036 & 1.721 \\
\hline Subtotal & & - & 229 & & & & & & & \\
\hline Monterey Peninsula Subtotals & & 36.77 & 27,578 & & & & 933.7 & & & \\
\hline \multicolumn{11}{|l|}{ Bay/Estuary (Elkhorn Slough) } \\
\hline MNT-228 & Middle & 1.10 & 3416 & Silversides & 1279 & 37.4 & 3105.5 & 22 & 2.581 & 2.673 \\
\hline MNT-234 & Middle & 0.45 & 1020 & Herrings & 290 & 28.4 & 2266 & 25 & 3.464 & 3.52 \\
\hline Subtotal & & 1.55 & 4436 & & & & 2862 & & & \\
\hline MNT-234 & Early & 0.46 & 9592 & Right-eyed flounders & 4406 & 45.9 & 20,852 & 28 & 3.188 & 3.134 \\
\hline Subtotal & & 0.46 & 9592 & & & & 20,852 & & & \\
\hline MNT-228 & Milling & 0.80 & 47 & Bat ray & 9 & 19.4 & 59 & 13 & 3.116 & 5.235 \\
\hline MNT-234 & Milling & 1.60 & 853 & Silversides & 211 & 19.8 & 533 & 24 & 3.299 & 5.05 \\
\hline MNT-1570 & Milling & 0.60 & 145 & Sacramento perch & 42 & 32.8 & 242 & 16 & 3.091 & 3.048 \\
\hline Subtotal & & 3.00 & 1045 & & & & 348.3 & & & \\
\hline Estuarine Subtotals & & 5.01 & 15,073 & & & & 3008.6 & & & \\
\hline
\end{tabular}

a Includes some Middle Period specimens.

herrings. The dominant species represented in components along the Monterey Peninsula is biased $\left(\chi^{2}=11.33, \mathrm{df}=3\right.$, $p$-value $=0.0101)$, toward the herrings family, possibly Pacific sardines, which dominates nine of the temporal components; the others are dominated by rockfishes ( 7 components), cabezon (1 component), and surfperches (1 component) (Appendix A, Supplementary Tables 3, 5, 7, 9 and 11).

\subsubsection{Bay/estuaries}

The two estuarine systems, Elkhorn Slough and Morro Bay, differ significantly from one another in the dominant taxa $\left(\chi^{2}=11.76\right.$, $\mathrm{df}=5, p=0.0382$ ), although both produced the greatest volumetric fish bone density figures for each of the recovery methods, and it is apparent that they represent the richest prehistoric fisheries. The sample from Elkhorn Slough is more temporally limited, and also shows more variability in the dominant fish groups. Six temporal components associated with that estuary show four different dominant fish groups: New World silversides (three components), herrings (one component), bat ray (one component), and Sacramento perch (one component). The latter is the only instance of a component dominated by a freshwater species. Morro Bay shows much less variability with 11 components dominated by surfperches, New World silversides (three components), herrings (two components), and Pacific staghorn sculpin (one component) (Appendix 
Table 6

Summary of study components over time.

\begin{tabular}{|c|c|c|c|c|c|}
\hline \multirow[t]{2}{*}{ Period } & \multirow[t]{2}{*}{ Open coast } & \multicolumn{2}{|l|}{ Estuary } & \multirow[t]{2}{*}{ Monterey Peninsula } & \multirow[t]{2}{*}{ Total } \\
\hline & & Elkhorn Slough & Morro Bay & & \\
\hline Late & 8 & 0 & 2 & 6 & 16 \\
\hline Middle-Late & 5 & 0 & 1 & 4 & 10 \\
\hline Middle & 4 & 2 & 4 & 3 & 13 \\
\hline Early & 12 & 1 & 5 & 4 & 22 \\
\hline Millingstone/Archaic & 2 & 3 & 5 & 1 & 11 \\
\hline Total & 31 & 6 & 17 & 18 & 72 \\
\hline
\end{tabular}

A, Supplementary Tables 2-11). The New World silversides are strong indicators of fishing with nets, while the surfperches are suggestive of net use but are less definitive. A study by Bertrando and McKenzie (2011) also concluded that nets were used from the very beginning at the Morro Bay estuary.

\subsection{Diachronic synthesis}

Patterns over time are complex and do not exhibit a singular unified trend across all environments. With respect to the relative importance of fish in general as suggested by fish bone density $\left(\mathrm{NISP} / \mathrm{m}^{3}\right)$, it is abundantly clear that fish bones and fishing did not simply increase linearly through the Holocene. There are no significant linear trends in mean fish bone density from the wetscreened sample along the exposed rocky coast $(\tau=2, p=0.75$ ) or on the Monterey Peninsula ( $\tau=4, p=0.75$; Fig. 5a); nor are there significant linear trends in mean fish bone density in the dryscreened sample in either habitat (rocky coast: $\tau=4, p=0.82$; Morro Bay/Halcyon Bay: $\tau=2, p=0.23$; Fig. 5). Nearly all of the highest fish bone density values pre-date the onset of the Late Period. The highest in the sample are from Early Period components on the Monterey Peninsula at CA-MNT-108 (Breschini and Haversat, 1989) and at CA-MNT-234 at the Elkhorn Slough estuary (Breschini and Haversat, 1995) (Fig. 2). Averaged temporal wetscreened samples show the peak in fishing at Elkhorn Slough estuary during the Early Period and on the open coast during the Middle-Late Transition (Fig. 5). Dry-screened residues from the open coast and Morro Bay/Halcyon Bay paleo-estuary also exhibit peak values during the Middle-Late Transition (Fig. 5). For the overall regional sample, fishing seems to have been more economically significant prior to the onset of the Late Period when most areas and recovery methods actually show a decline.

The only species that shows significant diachronic decline is the bat ray which represents $4.9-7.5 \%$ of assemblages from estuaries during the Millingstone/Lower Archaic Period (Appendix A, Supplementary Tables 2 and 3 ) but is essentially absent from nearly all settings after $3000 \mathrm{cal}$ BP (Appendix A, Supplementary Tables 7-11). Broughton et al. (2015) rank this species high due to its size, and would likely attribute its decreasing numbers over time to resource depression. Boone (2012), however, noted the same pattern in the Monterey Bay area, but attributed it to sedimentation (accompanying sea level rise) and decreases in bat ray habitat. At Morro Bay, Jones et al. (2015) attributed it to a change in seasonality as bat rays are strictly summertime visitors to central coast estuaries (Love, 2011:75). None of these alternative explanations can be ruled out so a definitive case for human impact on this species cannot be established.

Diachronic trends in assemblage diversity are also non-linear. Variation in Margalef's Index values (Fig. 6) do not differ significantly from one another with either the wet-screened $\left(\chi^{2}=5.42\right.$, $\mathrm{df}=4, p=0.25)$ or dry-screened $\left(\chi^{2}=1.83, \mathrm{df}=4, p=0.77\right)$ samples. While the Millingstone/Lower Archaic Period does represent highest diversity of species in the wet-screened sample, which may correspond with indiscriminant net fishing, the differences are not significant. Variation in fish assemblage evenness (1/Berger-Parker) also shows that there are no significant differences in the wet-screened $\left(\chi^{2}=6.13, \mathrm{df}=4, p=0.19\right)$ or dry-screened $\left(\chi^{2}=3.70, \mathrm{df}=4, p=0.34\right)$ samples between time periods (Fig. 7 ). However, there is a marginal tendency for the median values in dietary evenness from the wet-screened sample (Fig. 7) to decline gradually overtime $(\tau=0.21, p=0.0987)$, indicating
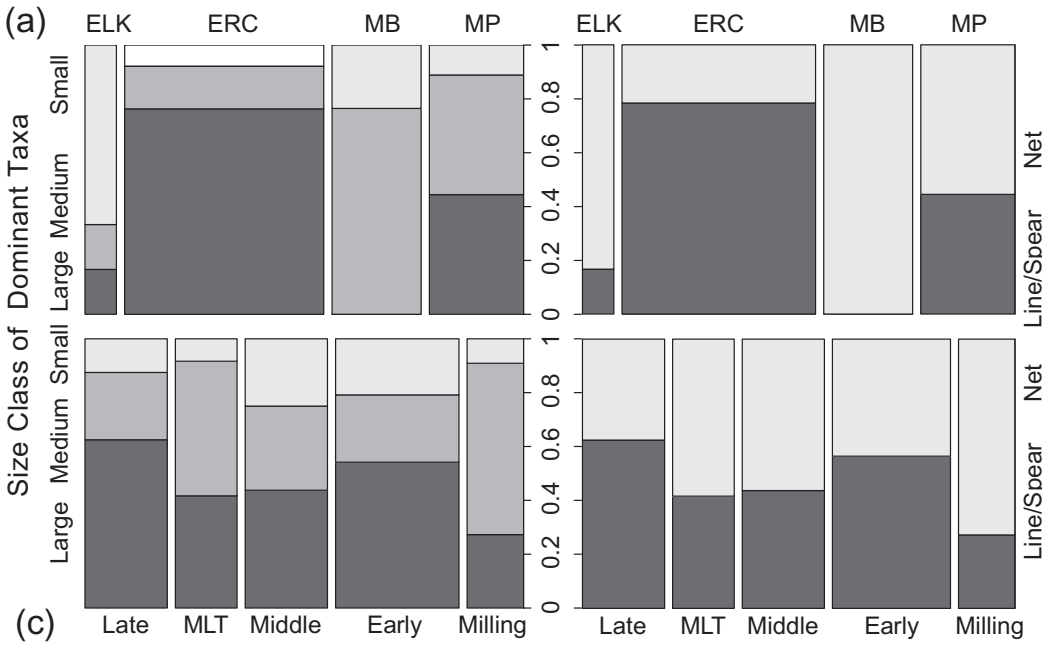

(b)

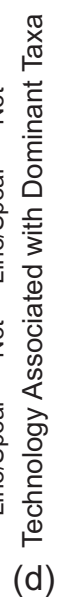

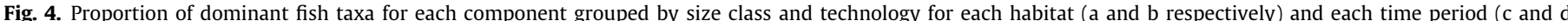

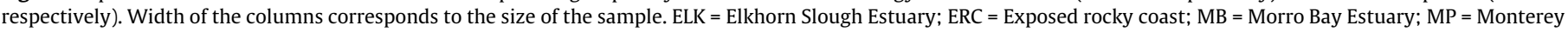
Peninsula; MLT = Middle-Late Transition Period; Milling = Millingstone/Lower Archaic Period. 


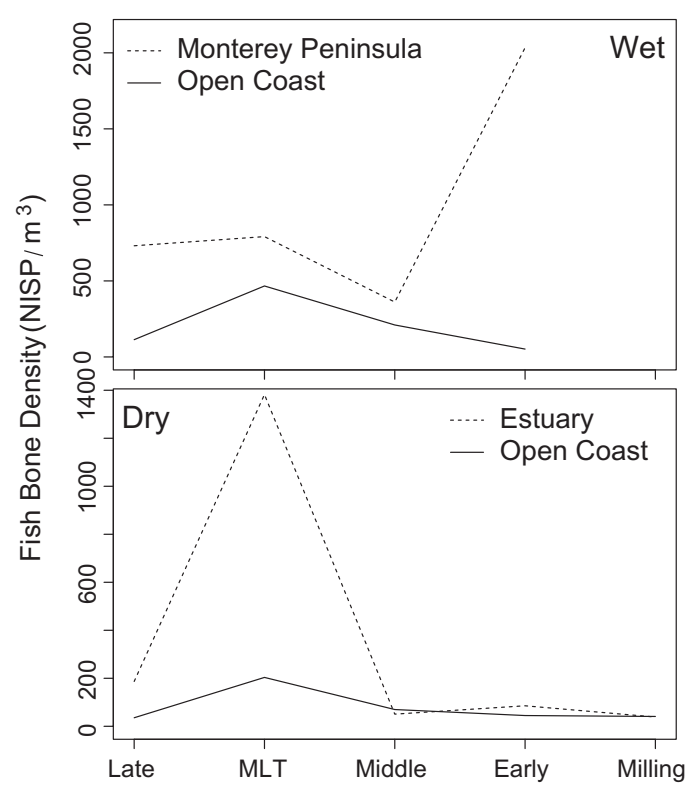

Fig. 5. Mean fish bone density by volume across each habitat over time for the wet(above) and dry-screened (below) samples.

increasing specialization. This pattern does not hold over the Middle-Late Transition Period, however, when evenness increases.

Diachronic patterning in size classes and technology is equally complex. Size classes of the dominant fish groups, summarized in Fig. 4c do not vary significantly through time in either the wetscreened $\left(\chi^{2}=7.41, \mathrm{df}=8, p=0.49\right)$ or the dry-screened samples $\left(\chi^{2}=7.47, \mathrm{df}=8, p=0.48\right)$. Similarly, there are no significant diachronic trends across components in the technology used to capture the dominant fishes with either the wet-screened $\left(\chi^{2}=3.81\right.$, $\mathrm{df}=4, p=0.43)$ or dry-screened $\left(\chi^{2}=2.99, \mathrm{df}=4, p=0.56\right)$ samples. These patterns are similar given that most large fish in the region are caught via individual capture methods.

The limited change over time that is present probably results from the interaction between fish species, technology and habitat. The Millingstone/Lower Archaic components show strong evidence for reliance on nets because of the dominance of small fishes (Fig. 4d), however, there is distinctive regional variation. The southern estuaries show high frequencies of New World silversides (Appendix A, Supplementary Table 2), schooling fishes that seem to be especially reliable indicators of net use. This species, however, is nearly absent from the comparably dated components from Elkhorn Slough which makes the inference for net use at that setting less definitive for the Millingstone/Lower Archaic Period. After ca. 5500 cal BP, however, New World silversides represent over 30\% of the Early Period component from CA-MNT-234 at Elkhorn Slough. This dramatic shift in species suggests the possibility that netting was pursued here for the first time ca. $5500 \mathrm{cal}$ BP while it was already the dominant technology at the southern estuaries. Unfortunately, the artifact record from Elkhorn Slough is moot on this possible transition as no net weights have been recovered from the area from early Holocene contexts. Overall, however, the shift that is most apparent at the onset of the Early Period is the heavy increase in single-target species by line or spear. This trend is clearly related to the increase in the number of sites occupied on the open coast at this time (Table 6). No technological change can be tied to this increase, archaeologically, however.

Changes in fish remains across the Early-Middle Period threshold when shell fishhooks first appeared is also very modest. Dryscreened residues from the open coast and southern estuaries show increases in fish remains as do wet-screened samples from the open coast, but the wet-screened samples from the northern
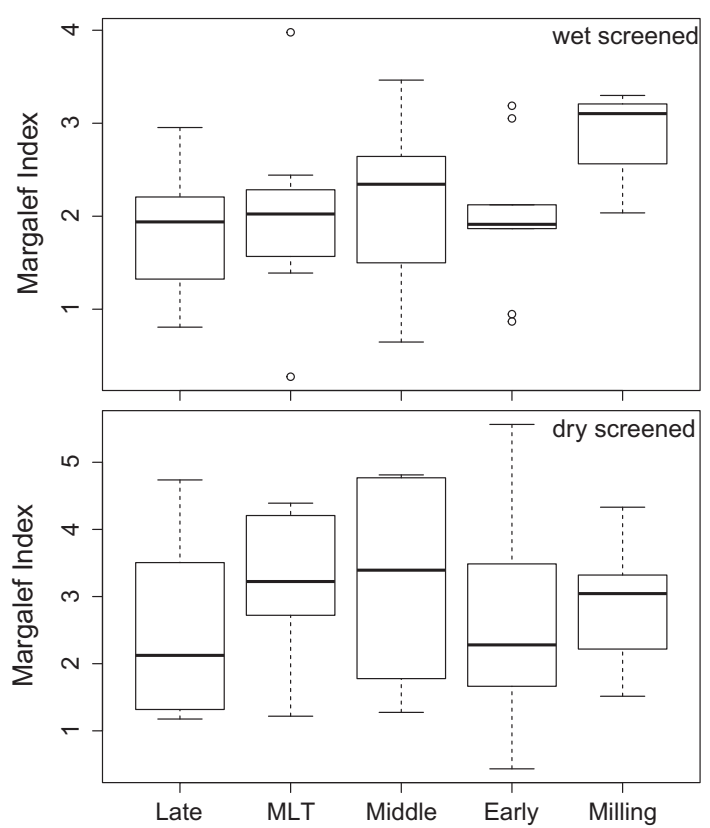

Fig. 6. Boxplots showing the distribution of Margalef's Diversity values over time for the wet- (above) and dry-screened (below) samples. MLT = Middle-Late Transition Period; Milling = Millingstone/Lower Archaic.
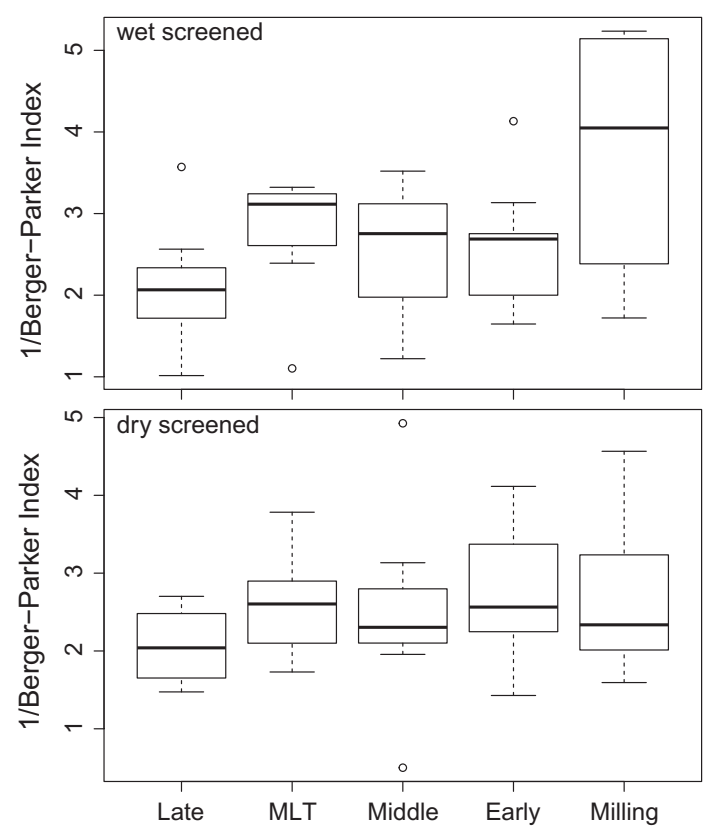

Fig. 7. Boxplots showing the distribution of Reciprocal Berger-Parker Evenness values over time for the wet- (above) and dry-screened (below) samples. Lower values indicate greater specialization. MLT $=$ Middle-Late Transition Period; Milling = Millingstone/Lower Archaic.

estuary and Monterey Peninsula show slight decreases and no significant change in dominant species. The reduced abundance of fish remains during the Middle Period in the Monterey area probably reflects low human presence in the area during the early Middle Period as reflected by the gap in the local radiocarbon record identified by Breschini and Haversat (2011). The appearance of shell fishhooks may have had a small impact on the more southern fishing practices, but it does not seem to have affected major change throughout the study region. Overall, no significant 
increase in individual species capture can be associated with the Middle Period.

Variability associated with the Middle-Late Transition is limited to the afore-mentioned peaks in NISP $/ \mathrm{m}^{3}$ which are most evident in the dry-screened residues from the open coast and southern estuaries, but also represented in the wet-screened samples. In the southern half of the study area the Middle-Late Transition is marked by the appearance of a new form of stone sinker that Codding and Jones (2007) interpreted as a line sinker used with hooks rather than nets. However, the meta-sample shows no increase in hook and line fishing at this point in the sequence and dietary evenness actually increases, as would be expected with a generalized netting strategy. A distinctive increase in hook-andline fishing is evident during the Late Period although it also correlates with the afore-mentioned overall decrease in fishing during the Late Period.

The Late Period trends further are associated with a significant decrease in the Berger-Parker (relative evenness) index in both the wet-screened and dry-screened remains (Fig. 7). Although there is no significant temporal variation in Margalef's Index (diversity) values (Fig. 6) the decrease in evenness during the Late Period suggests at least a modicum of specialization. Recognized previously by Jones and Codding (2012), such specialization is consistent with ethnographically described sardine fishing in the Monterey Peninsula area (Breschini and Haversat, 1994). Remarkably, the Late Period sites producing the highest frequency of the bones of herrings (CA-MNT-1485/H and $-1486 / \mathrm{H}$ ) are situated ca. $30 \mathrm{~km}$ inland in the headwaters of the Carmel Valley. After the Middle Period fishing seems to have become a specialized, seasonally-restricted activity that involved brief seasonal trips to the coast where watercraft was relied upon to pursue herrings (probably sardines) and transport catches inland as part of an overall economy that was more terrestrially focused. Pricklebacks which can be taken by hand nearshore and seem to have always been a component of shoreline-based fishing practices are absent from the inland, sites rich in the bones of herrings of the upper Carmel Valley support the notion that was a profoundly different strategy for exploiting marine fish than had been used previously. That specialized, more seasonally restricted fishing was limited to the Monterey Peninsula suggests culturally mediated variation in settlement and fishing practices between the Costanoan-speaking peoples on the Peninsula and other groups to the south where no such Late Period specialization is apparent.

Overall, temporal variation in fish bone assemblages at this regional scale seems to reflect the dominant habitats that people occupied. For example, time periods when more sites occur adjacent to estuarine habitats, fish bone assemblages will reflect smaller, net caught fish; when more sites are located along exposed rocky coastlines, fish bone assemblages will reflect larger, individually caught fish. Because fishing profitability varies both with the size of the fish and the technology, these findings suggest that individuals along the central California coast were always working to acquire the most profitable fish relative to their local habitat (individually capturing large fish when available, or netting small fish when available), with little diachronic variation when habitats are held constant. The limited diachronic changes show that there is no evidence for overexploitation.

\subsection{Comparison with historic catch records}

While the modern catch records, of course, represent technologies for mass capture beyond the capabilities of prehistoric people as well as distances traveled offshore, they nonetheless provide data for comparison in terms of the amount of food available in offshore waters. Initial commercial fishing from the port of Morro Bay was focused on two deep water species: albacore tuna and sardines
(Table 7). Albacore are exclusively pelagic and have never been found in significant numbers in the central coast archaeological record. Sardines, on the other hand, spawn inshore (but also occur 300 miles offshore), are found in the archaeological record, and were noted in ethnographic accounts from Monterey (see above). The historic center of sardine fishing was the port of Monterey where this was the single most important commercial fish in California until its well-documented collapse in the 1940s. During the first year for which commercial records are available for the Port of Morro Bay (1947), 220,439 lb of albacore were reported (California Department of Fish and Game, 1976). Sardines appear for the first time in 1950 when 8,807,055 lb were recorded. As the commercial fishery expanded over the following 50 years, fishermen increasingly exploited nearshore species in addition to the pelagic ones - tapping some of the same fishes caught prehistorically. Rockfish were taken for the first time in 1950, and in 1955 over 3 million pounds were recorded at the port. The total from 1950 to 2010 was over 107 million pounds of rockfish. Multiple factors influenced yields over the decades including changes in regulations, numbers of boats, consumer tastes, and market prices. Fluctuations can be seen between sardines and anchovies which biologists attribute to oscillations in temperature regimes (Chavez et al., 2003). Yields in recent decades of many species are noticeably lower than those from the 1950s which can be attributed to large-scale commercial overharvest (see discussion by Jackson et al., 2001). However, it would be untenable to suggest that indigenous fishing in this region ever reached the magnitude that it accomplished the same thing. With only 13,000 people spread between Morro Bay and Monterey Bay prehistorically, the sardine fishery alone on this upwelling-fueled coastline was productive enough to sustain substantially higher human populations. And, if crashes in sardine populations occurred, there is evidence for exploitation of over 80 other species.

\section{Summary and discussion}

The meta-dataset shows only very modest changes between 10,000 and 300 years ago, and further suggests continuous harvest of a relatively productive, stable resource that was too abundant to be seriously impacted by pre-European populations. There is no evidence for gradual or incremental intensification in fishing, rather there are three intervals of change in fish remains and inferred fishing practices that seem best explained by external factors of human population and/or environment rather than any changes in productivity of the fishery: one at 5500 cal BP (the transition from Millingstone/Lower Archaic to Early Period) when there is an apparent increase in hook and line/spear (individual pursuit), second, increases during the Middle-Late Transition, and third at the onset of the Late Period, when the volumetric density of fish bone decreases and diversity declines.

The $5500 \mathrm{cal}$ BP date has been previously associated with a major cultural transition along the central coast (Jones, 1992; Jones et al., 2007) when human settlements become more visible, numerous, and functionally diverse (Bertrando, 2006; Codding et al., 2012). Whether this reflects climatic amelioration at the end of early-mid Holocene warming (Mikkelsen et al., 2000), the appearance of new cultural groups (Moratto, 1984), a demographic threshold (Jones, 1996), or some combination thereof, remains unclear, but these changes can be accurately described as an interval of modest increase in fishing. Nets were clearly used from the very beginning, and were actually most important in the earliest millennia of the Holocene. Rick and Erlandson (2000) reported similar evidence for early Holocene net use on the mainland of the Santa Barbara coast. This may reflect a bias toward the exploitation of highly productive environments, such as estuaries 
Table 7

Annual landings by select species for the port of Morro Bay, 1947-2010 (compiled by Schmicking (2012) from California Department of Fish and Game, 1976, 2010).

\begin{tabular}{|c|c|c|c|c|c|c|c|c|c|}
\hline & & 1947-1950 & $1951-1960$ & $1961-1970$ & 1971-1980 & 1981-1990 & $1991-2000$ & 2001-2010 & Total \\
\hline Elasmobranchiomorphi & Sharks, skates, and rays & & & & & & & & \\
\hline Heterodontus francisci & Horn shark & 0 & 0 & 0 & 41 & 0 & 0 & 0 & 41 \\
\hline Isurus oxyrinchus & Shortfin mako & 0 & 0 & 0 & 1134 & 161,554 & 97,374 & 43,106 & 303,168 \\
\hline Galeorhinus galeus (G. zyopterus) & Tope (soupfin shark) & 0 & 0 & 0 & 19,451 & 180,791 & 58,850 & 8626 & 267,718 \\
\hline Triakis semifasciata & Leopard shark & 0 & 0 & 0 & 3076 & 34,418 & 4166 & 750 & 42,410 \\
\hline Squatina californica & Pacific angel shark & 0 & 0 & 0 & 47,817 & 580,660 & 73,763 & 5,882 & 708,122 \\
\hline Rhinobatos productus & Shovelnose guitarfish & 0 & 0 & 0 & 0 & 23,671 & 6984 & 422 & 31,077 \\
\hline Myliobatis californica & Bat ray & 0 & 0 & 0 & 0 & 378 & 0 & 396 & 774 \\
\hline Subtotal & & 0 & 0 & 0 & 71,519 & 981,472 & 241,137 & 59,182 & $1,353,310$ \\
\hline Actinopterygii & Ray-finned fishes & & & & & & & & \\
\hline Engraulis mordax & Northern anchovy & 0 & 0 & 0 & 26,555 & 155,831 & 53,534 & 16,382 & 252,302 \\
\hline Sardinops sagax & Pacific sardine & $8,807,055$ & $38,762,160$ & $4,215,938$ & 0 & 267,562 & 248 & 9,603 & $52,062,566$ \\
\hline Porichthys notatus & Plainfin midshipman & 0 & 0 & 0 & 0 & 50 & 0 & 0 & 50 \\
\hline Atherinopsidae & New World silversides & 0 & 0 & 0 & 1158 & 68 & 6 & 0 & 1232 \\
\hline Gasterosteus aculeatus & Threespine stickleback & 0 & 0 & 0 & 0 & 0 & 3 & 0 & 3 \\
\hline Sebastes spp. & Rockfishes & 90,913 & $14,437,245$ & $12,896,607$ & $27,170,756$ & $33,423,838$ & $17,694,067.00$ & $1,361,926$ & $107,075,352$ \\
\hline Anoplopoma fimbria & Sablefish & 0 & 0 & 0 & $3,148,445$ & $5,490,059$ & $3,566,077$ & $3,984,764$ & $16,189,345$ \\
\hline Hexagrammos decagrammus & Kelp greenling & 0 & 0 & 0 & 0 & 65 & 20,977 & 18,189 & 39,231 \\
\hline Ophiodon elongatus & Lingcod & 0 & 405,404 & 163,663 & $3,246,038$ & $1,326,064$ & 665,453 & 90,321 & $5,896,943$ \\
\hline Leptocottus armatus & Pacific staghorn sculpin & 0 & 0 & 0 & 0 & 0 & 45 & 0 & 45 \\
\hline Scorpaenichthys marmoratus & Cabezon & 0 & 0 & 0 & 109,145 & 67,116 & 987,111 & 262,900 & $1,426,272$ \\
\hline Trachurus symmetricus & Jack mackerel & 0 & $3,328,247$ & $12,208,273$ & 0 & 110,398 & 4556 & 121 & $15,651,595$ \\
\hline Genyonemus lineatus & White croaker & 0 & 0 & 0 & 124,375 & 397,445 & 145,826 & 0 & 667,646 \\
\hline Embiotocidae & Surfperches & 0 & 0 & 0 & 129,384 & 267,981 & 319,331 & 49,846 & 766,542 \\
\hline Sarda chiliensis & Pacific bonito & 0 & 0 & 0 & 1520 & 756,584 & 4259 & 856 & 763,219 \\
\hline Thunnus alalunga & Albacore tuna & $1,783,065$ & $9,978,232$ & $23,140,651$ & $21,173,072$ & $7,671,882$ & $2,011,231$ & $2,357,494$ & $68,115,627$ \\
\hline Pleuronectiformes & Flounders and Soles & 0 & $2,529,894$ & $2,266,330$ & $5,761,973$ & $34,677,424$ & $26,489,752$ & $1,786,389$ & $73,511,762$ \\
\hline Citharichthys sordidus & Pacific sanddab & 0 & 0 & 0 & 15,882 & $4,000,830$ & 287,054 & 9,871 & $4,313,637$ \\
\hline Paralichthys californicus & California halibut & 0 & 0 & 190,247 & 0 & $2,075,579$ & 737,404 & 53,331 & $3,056,561$ \\
\hline Pleuronichthys spp. & Turbot & 0 & 0 & 0 & 21,672 & 0 & 0 & 0 & 21,672 \\
\hline \multirow[t]{2}{*}{ Subtotal } & & $10,681,033$ & $69,441,182$ & $55,081,709$ & $60,929,975$ & $90,688,776$ & $52,986,934$ & $10,001,993$ & $349,811,602$ \\
\hline & & 0 & 0 & 0 & $87,902,574$ & $139,114,491$ & $82,512,375$ & $14,209,078$ & $323,738,518$ \\
\hline Grand total & & $10,681,033$ & $69,441,182$ & $55,081,709$ & $148,832,549$ & $229,803,267$ & $61,499,309$ & $24,211,071$ & $673,550,120$ \\
\hline
\end{tabular}

(Jones, 1991), where nets were necessary equipment to acquire high-profitability fish resources. Nets require substantial investments of time and energy to produce (Lindstrom, 1996:138 suggest over $1400 \mathrm{~h}$ for a gill net) and maintain, thereby representing a labor-intensive subsistence regime that would make sense only for people who already committed themselves to a maritime way of life (Bettinger et al., 2006). In this light, net use early in the Holocene would seem to represent something developed, and subsequently maintained, through a process of coastal migration into the New World. The technological change represented at this point in time (Fig. $4 \mathrm{~b}$ and d) is likely an expression of larger changes in settlement locations tied to demographic pressure in the highly productive estuarine environments which pushed people into less suitable open coastline habitats (Codding et al., 2012). While the appearance of curved shell hooks may have altered the character of fishing in the Santa Barbara Channel during the Middle Period as McKenzie (2007) suggests, their appearance on the central coast is not associated with punctuated changes in the relative frequency of fish remains, and seems merely a case of diffusion not major technological advancement. Furthermore, we can detect no clear temporal directionality in the diversity of fish remains, only a tendency for bay/estuaries to show the highest diversity values.

The only period representing relatively high average fish bone density across all sampling methods and habitats is the MiddleLate Transition Period. This second, more punctuated increase in fishing during the Middle-Late Transition seems to reflect intensified use of marine foods when terrestrial productivity was reduced during droughts of the Medieval Climatic Anomaly (Codding et al., 2010; Jones et al., 1999; Jones and Kennett, 1999; Jones and Ferneau, 2002; Joslin, 2010; Mikkelsen et al., 2000) and sea surface temperatures were generally cold and highly productive (Kennett and Kennett, 2000). The density of fish remains from many Late Period sites is lower than earlier periods. This seems consistent with the notion that fish (and other marine foods) gave way to acorns as the major subsistence focus in this region during the last half millennium of prehistory (Bettinger, 2015). Furthermore, there is little to suggest that changes in technology affected subsistence change. Climatic amelioration following the MCA shows a decrease in fishing and increased specialization which suggests more seasonally restricted, targeted fishing at least among the Costanoanspeaking tribelets of the northern study area. We believe the latter trend suggests more seasonally-restricted, targeted fishing consistent with ethnographic observations in the Monterey Bay area (Breschini and Haversat, 1994).

\section{Conclusions}

Evaluation of a meta-dataset of over 200,000 fish bones from 86 sites representing the period between 10,000 and 300 years ago shows only modest changes that are readily attributed to intervals of modest human population growth and/or changes in climate. Fishing increased slightly when human numbers went up at midHolocene and when terrestrial productivity declined during late Holocene drought. Advances in technology seem unrelated to these brief intervals of fishing increase. Fish were caught with nets and watercraft from the very beginning of the sequence, and those technologies seem to have dominated throughout. There are no changes in dominant species that suggest reduction of a topranked species and resort to lower-ranked, more labor-intensive fish. The abundant regional fishery, fueled by marine upwelling, seems to have been very minimally affected by pre-contact human exploitation, the catches from which were decidedly lower that the 
huge numbers of fish caught by commercial boats in the 20th century. The prehistoric resource, however, was under-exploited and was relied upon to yield more food whenever more was needed. The combination of a relatively low human population and highly productive fishery resulted in a clear case of epiphenomenal sustainability, fostering a situation different from that of coastal southern Mexico where Kennett et al. (2008) detected Archaic Period human-induced impacts on fisheries. There, however, human populations were increasing at rates that would eventually lead to dense urban settlements and civilizations later in the Holocene, and the fishery, in a non-upwelling zone, was less abundant.

Some of the variation in fishing practices and technology also seems more influenced by historical contingencies. The use of nets from the very beginning seems largely the result of a marine tradition brought into the New World by coastal migrants. The appearance of curved shell hooks seems more related to diffusion of this type of hook from the south rather than a development needed to procure more food. During the Late Period fishing seems to have given way to the acorn economy which, if Bettinger (2015) is right, had its roots in the introduction of the bow and arrow to eastern California in the first millennium AD. The timing of the subsequent diffusion of the bow and arrow further west to the central coast coincides with evidence for increased acorn exploitation and less emphasis on fishing even though the latter could have certainly provided more food if needed. That historical contingency could influence these technological changes seems consistent with the notion that Native populations in California were below carrying capacity as suggested by Baumhoff (1963). Based on different calculations Baumhoff (1979) later changed his mind, at least based on the carrying capacity of a human population dependent on acorns. Nonetheless, along the central coast human populations were positioned along the interface between enormous ocean fisheries and extensive acorn-bearing oak woodland that could have sustained more than the 13,000 people present there at the time of contact.

\section{Acknowledgments}

We would like to thank Gary S. Breschini for providing us with much of his recently acquired excavation data, and Darren Schmicking for compiling historic catch data from Department of Fish and Game sources. We are also indebted to two anonymous reviewers who offered excellent suggestions for improving the manuscript.

\section{Appendix A. Supplementary material}

Supplementary data associated with this article can be found, in the online version, at http://dx.doi.org/10.1016/j.jaa.2015.11.002.

\section{References}

Anderson, A., 2008. Short and sometimes sharp: human impacts on marine resources in the archaeology and history of South Polynesia. In: Rick, T.C., Erlanson, J.M. (Eds.), Human Impacts on Ancient Marine Ecosystems. University of California Press, Berkeley, pp. 21-42.

Arnold, J.E., 1992. Complex hunter-gatherer-fishers of prehistoric California: chiefs, specialists, and maritime adaptations of the Channel Islands. Am. Antiq. 57, 6084.

Arnold, J.E., 1995. Transportation innovation and social complexity among maritime hunter-gatherer societies. Am. Anthropol. 97, 733-747.

Arnold, J.E. (Ed.), 2001. The Origins of a Pacific Coast Chiefdom: The Chumash of the Channel Islands. University of Utah Press, Salt Lake City.

Arnold, J.E. (Ed.), 2004. Foundations of Chumash Complexity. Cotsen Institute of Archaeology, University of California, Los Angeles.

Baumhoff, M.A., 1963. Ecological determinants of Aboriginal California populations. In: University of California Publications in American Archaeology and Ethnology, vol. 49, no. 2, pp. 155-236.
Baumhoff, M.A., 1979. The carrying capacity of hunter-gatherers. In: Koyama, S. Thomas, D.H. (Eds.), Affluent Foragers: Pacific Coasts East and West. Senri Ethnological Studies No. 9. National Museum of Ethnology, Osaka, Japan.

Bertrando, E., 2006. Hunter-gatherers in the Morro Bay watershed 3650 years ago: settlement, subsistences, and technology during an archaeological point in time. Proc. Soc. Calif. Archaeol. 19, 211-219.

Bertrando, E., McKenzie, D.K., 2011. Identifying fishing techniques from the skeletal remains of fish. In: Glassow, M.A., Joslin, T.L. (Eds.), Exploring Methods of Fauna Analysis: Perspectives from California Archaeology. Cotsen Institute Press, University of California, Los Angeles, pp. 187-198.

Bettinger, R.L., 2015. Orderly Anarchy: Sociopolitical Evolution in Native California. University of California Press, Berkeley.

Bettinger, R.L., Winterhalder, B., McElreath, R., 2006. A simple model of technological intensification. J. Archaeol. Sci. 35, 538-545.

Bird, D.W., O'Connell, J.F., 2006. Behavioral ecology and archaeology. J. Archaeol. Res. 14, 143-188.

Bliege Bird, R., Bird, D.W., 1997. Delayed reciprocity and tolerated theft: the behavioral ecology of food-sharing strategies. Curr. Anthropol. 38, 49-78.

Boone, C.M., 2012. Integrating Zooarchaeology and Modeling: Trans-Holocene Fishing in Monterey Bay, California. Unpublished Ph.D. Dissertation, Department of Anthropology, University of California, Santa Cruz.

Botkin, S., 1980. Effects of human exploitation on shellfish populations at Malibu Creek, California. In: Eark, T.K., Christenson, A.L. (Eds.), Modeling Change in Prehistoric Subsistence Economies. Academic Press, New York, pp. 121-139.

Breschini, G.S., Haversat, T., 1980. Preliminary Archaeological Report and Archaeological Management Recommendations for CA-MNT-170, on Pescadero Point, Monterey County, California. Archaeological Consulting, Salinas, California. Copies available from Northwest Archaeological Information Center, Sonoma State University, Rohnert Park.

Breschini, G.S., Haversat, T., 1989. Archaeological investigations at CA-MNT-108 at Fisherman's Wharf, Monterey, Monterey County, California. Archives of California Prehistory, vol. 29. Coyote Press, Salinas, California.

Breschini, G.S., Haversat, T., 1994. Rumsen seasonality and population dynamics. In: Bean, L.J. (Ed.), The Ohlone Past and Present: Native Americans of the San Francisco Bay Region. Ballena Press, Menlo Park, CA, pp. 193-202.

Breschini, G.S., Haversat, T., 1995. Archaeological Evaluation of CA-MNT-234, at the Site of the Proposed Moss Landing Marine Laboratory, Moss Landing, Monterey County, California. Archaeological Consulting, Salinas, California. Copies available from Northwest Archaeological Information Center, Sonoma State University, Rohnert Park.

Breschini, G.S., Haversat, T., 2000. Archaeological Radiocarbon Dating of a Portion of CA-MNT-103, Monterey, Monterey County, California. Archaeological Consulting, Salinas, California. Copies available from Northwest Archaeological Information Center, Sonoma State University, Rohnert Park.

Breschini, G.S., Haversat, T., 2011. A revised culture sequence for the Monterey Peninsula area, California. Pac. Coast Archaeol. Soc. Q. 44 (3), 1-24.

Broughton, J.M., 1994. Late Holocene resource intensification in the Sacramento River Valley, California: the vertebrate evidence. J. Archaeol. Sci. 21 501-514.

Broughton, J.M., 1997. Widening diet breadth, declining foraging efficiency, and prehistoric harvest pressure: ichthyofaunal evidence from the Emeryville Shellmound, California. Antiquity 71, 845-862.

Broughton, J.M., 2004. Prehistoric human impact on California birds: evidence from the Emeryville shellmound avifauna. Ornithological Monographs No. 56.

Broughton, J.M., Martin, E.P., McEneaney, E.M., Wake, T., Simons, D.D., 2015. Late Holocene anthropogenic depression of Sturgeon in San Francisco Bay, California. J. Calif. Great Basin Anthropol. 35, 3-27.

Butler, V.L., Campbell, S.K., 2004. Resource intensification and resource depression in the Pacific Northwest of North America: a zooarchaeological review. J. World Prehist. 18, 327-404.

California Department of Fish and Game, 1976. Fish bulletin fish catch statistics: Values of landings and shipments by port for the years 1947-1976. California Department of Fish and Game, Sacramento.

California Department of Fish and Game, 2010. California Commercial Landings for 2000-2010 Available from: http://www.dfg.ca.gov/marine/fishing. asp\#Commercial. Accessed June 2012.

Cartier, R.R., 1993. The Saunders site: MNT-391, a littoral site of the early period. In Scotts Valley Historical Society Monograph, vol. 1. Scotts Valley, California.

Casteel, R.W., 1972. Some biases in the recovery of archaeological faunal remains. Proc. Prehist. Soc. 38, 382-388.

Charnov, E.L., 1976. Optimal foraging: attack strategy of a Mantid. Am. Nat. 110, $141-151$.

Chavez, F.P., Ryan, J., Lluch-Cota, S.E., Niquen, M., 2003. From anchovies to sardines and back: multidecadal change in the Pacific Ocean. Science 299, 217-221.

Codding, B.F., Bird, D.W., 2015. Behavioral ecology and the future of archaeological science. J. Archaeol. Sci. 56, 9-20.

Codding, B.F., Jones, T.L., 2007. History and behavioral ecology during the middlelate transition on the central California coast: findings from the Coon Creek Site (CA-SLO-9), San Luis Obispo County. J. Calif. Great Basin Anthropol. 27, 23-49.

Codding, B.F., Jones, T.L., 2013. Environmental productivity predicts migration, demographic and linguistic patterns in prehistoric California. Proc. Natl. Acad Sci. USA 110, 14569-14573.

Codding, B.F., Barton, A.M., Hill, E.J., Wheeler, E., Stevens, N.E., Jones, T.L., 2009. The Middle-Late Transition on the Central California Coast: Final Report on Salvage at CA-SLO-9, Montana de Oro State Park, San Luis Obispo County. Occasional Papers of the San Luis Obispo Archaeological Society, No, California, 19. 
Codding, B.F., Jones, T.L., Porcasi, J.F., 2010. Explaining prehistoric variation in the abundance of large prey: a zooarchaeological analysis of deer and rabbit hunting along the Pecho Coast of central California. J. Anthropol. Archaeol. 29, 47-61.

Codding, B.F., Bird, D.W., Jones, T.L., 2012. A land of work: foraging behavior and ecology. In: Jones, T.L., Perry, J. (Eds.), Contemporary Issues in California Archaeology. Left Coast Press, Walnut Creek, pp. 115-131.

Cook, S.F., 1978. Historical demography. In: Heizer, R.F. (Ed.), Handbook of North American Indians, vol. 8. Smithsonian Institution, Washington, DC, pp. 91-98.

Des Lauriers, M.R., 2010. Island of Fogs: Archaeological and Ethnohistorical Investigations of Isla Cedros. University of Utah Press, Salt Lake City, Baja California.

Dietz, S.A., 1987. Archaeological Test Excavations at CA-MNT-101, CA-MNT-298, CA-MNT-929, and El Castillo at the Presidio and City of Monterey, California. Archaeological Consulting and Research Services, Santa Cruz. Copies available from Northwest Archaeological Information Center, Sonoma State University, Rohnert Park, CA

Dills, C.E., 1981. Halcyon Bay: an ancient estuary. Society for California Archaeology Occasional Papers, vol. 3. California State University, Fullerton, pp. 43-48.

Erlandson, J.M., 1985. Early Holocene settlement and subsistence in relation to coastal paleogeography: evidence from CA-SBA-1807. J. Calif. Great Basin Anthropol. 7, 103-109.

Erlandson, J.M., 2001. The archaeology of aquatic adaptations: paradigms for a new millennium. J. Archaeol. Res. 9, 287-350.

Erlandson, J.M., 2002. Anatomically modern humans, maritime voyaging, and the Pleistocene colonization of the Americas. In: Jablonski, N.G. (Ed.), The First Americans: The Pleistocene Colonization of the New World, vol. 27. Memoirs of the California Academy of Sciences, pp. 59-92.

Erlandson, J.M., Rick, T.C., 2002. Late Holocene cultural developments along the Santa Barbara Coast. In: Erlandson, J.M., Jones, T.L. (Eds.), Catalysts to Complexity: Late Holocene Societies of the California Coast. Cotsen Institute of Archaeology, University of California, Los Angeles, pp. 166-182.

Erlandson, J.M., Rick, T.C., Jones, T.L., Porcasi, J.F., 2007. One if by land, two if by sea: who were the first Californians? In: Jones, T.L., Klar, K.A. (Eds.), California Prehistory: Colonization, Culture, and Complexity. AltaMira Press, Menlo Park, pp. 53-62.

Erlandson, J.M., Moss, M.L., Des Lauriers, M., 2008a. Life on the edge: early maritime cultures of the Pacific Coast of North America. Quatern. Sci. Rev. 27, 2232-2245.

Erlandson, J.M., Rick, T.C., Braje, T.J., Steinberg, A., Vellanoweth, R.L., 2008b. Human impacts on ancient shellfish: a 10,000 year record from San Miguel Island, California. J. Archaeol. Sci. 35, 2144-2152.

Erlandson, J.M., Rick, T.C., Braje, T.J., Casperson, M., Culleton, B., Fulfrost, B., Garcia T., Guthrie, D., Jew, N., Kennett, D.J., Moss, M.L., Reeder, L.A., Skinner, C., Watts, J. Willis, L., 2011a. Paleoindian seafaring maritime technologies, and coastal foraging on California's Channel Islands. Science 441, 1181-1185.

Erlandson, Jon M., Braje, Todd J., Rick, Torben C., Jew, Nicholas P., Kennett, Douglas J. Dwyer, Nicole, Ainis, Amira F., Vellanoweth, René L., Watts, Jack, 2011b. 10,000 years of human predation and size changes in the owl limpet (Lotti gigantea) on San Miguel Island, California. J. Archaeol. Sci. 38, 1127-1134.

Fages, P., 1937. A Historical, Political, and Natural Description of California (November 20, 1775) (H.E. Priestly, Trans.). University of California Press, Berkeley.

Fitch, J., 1972. Fish Remains, Primarily Otoliths from CA-SLO-2, Diablo Canyon. In Greenwood (Ed.), 9000 Years of Prehistory at Diablo Canyon, San Luis Obispo County, California, Occasional Paper No. 7, San Luis Obispo County Archaeological Society, San Luis Obispo, California, pp. 101-120.

Gamble, Lynn, 2008. The Chumash World at European Contact: Power, Trade, and Feasting among Complex Hunter-Gatherers. University of California Press, Berkeley.

Gause, S.L.S., 2002. Ecology and prey characteristics of fish species found in the vicinity of San Simeon Reef. In: Jones, T.L., Ferneau, J.A. (Eds.), Prehistory at San Simeon Reef: Archaeological Data Recovery at CA-SLO-179 and -267, San Luis Obispo County, California. San Luis Obispo County Archaeological Society Occasional Papers No. 16, pp. 409-427.

Glassow, M.A., 1993. Changes in subsistence on marine resources through 7,000 years of prehistory on Santa Cruz Island. In: Glassow, M.A. (Ed.) Archaeology on the Northern Channel Islands of California. Archives of California Prehistory, vol. 34. Coyote Press, Salinas, pp. 75-90.

Glassow, M.A., 2000. Weighing vs, counting shellfish remains: a comment on Mason, Peterson, and Tiffany. Am. Antiq. 6, 407-414.

Gobalet, K.W., 1990. Prehistoric status of freshwater fishes of the Pajaro-Salinas River system of California. Copeia, 680-685.

Gobalet, K.W., 1993. Additional archaeological evidence for endemic fishes of California's Central Valley in the coastal Pajaro-Salinas basin. Southwestern Nat. $38,218-223$

Gobalet, K.W., 2000. Has point conception been a marine zoogeographic boundary throughout the Holocene? Evidence from the archaeological record. Bull. Southern Calif. Acad. Sci. 99 (1), 32-44.

Gobalet, K.W., 2001. A critique of faunal analysis; inconsistency among experts in blind tests. J. Archaeol. Sci. 28, 377-386.

Gobalet, K.W., 2005. Comment on "Size Matters: 3-mm sieves do not increase richness in a fishbone assemblage from Arrawarra I, an Aboriginal Australian shell midden on the mid-north coast of New South Wales, Australia" by Vale and Gargett. J. Archaeol. Sci. 32, 643-645.

Gobalet, K.W., Jones, T.L., 1995. Prehistoric Native American fisheries of the Central California coast. Trans. Am. Fish. Soc. 124, 813-823.
Gobalet, K.W., Schulz, P.W., Wake, T.A., Siefken, N., 2004. Archaeological perspectives on Native American fisheries of California, with emphasis on steelhead and salmon. Trans. Am. Fish. Soc. 133, 801-833.

Gobalet, K.W., Hardin, K., 2009. Fish analysis. In: Pastron, A.A., Bellifemine, V. (Eds.), Archaeological Investigations at CA-CCO-235, City of Lafayette, Contra Costa County, California. Archives of California Prehistory Nos. 56 and 57. Coyote Press, Salinas, CA, pp. 222-231.

Golla, V., 2011. California Indian Languages. UC Press, Berkeley.

Gordon, B.L., 1979. Monterey Bay Area: Natural History and Cultural Imprints. Boxwood Press, Pacific Grove.

Gordon, Elizabeth A., 1993. Screen size and differential faunal recovery: a Hawaiian example. J. Field Archaeol. 20, 453-460.

Greenwood, R.S., 1972. 9000 Years of Prehistory at Diablo Canyon, San Luis Obispo County, California. San Luis Obispo County Archaeological Society Occasional Paper 7. San Luis Obispo.

Hadick, K., Jones, T.L., Cerles, E., Krause, D., Kuri, S., May, L., Munoz, L., Roth, L., 2012 Final Report on the Cal Poly 2009 Archaeological Field Class Investigation at CASLO-1370/H, Point Buchon San Luis Obispo County, California. California Polytechnic State University San Luis Obispo Corporation. Copies available from South Central Archaeological Information Center, Department of Anthropology, University of California, Santa Barbara.

Harden, D.R., 2004. California Geology. Pearson/Prentice Hall, Upper Saddle River, $\mathrm{NJ}$.

Heizer, R.F., 1950. On the Methods of Chemical Analysis of Bone as an aid to Prehistoric Cultural Chronology. University of California Archaeological Survey Report, vol. 7, pp. 10-14.

Hildebrandt, W.R., 1984. Late period hunting adaptations on the North Coast of California. J. Calif. Great Basin Anthropol. 6, 189-206.

Hildebrandt, W.R., Jones, T.L., 1992. Evolution of marine mammal hunting: a view from the California and Oregon Coasts. J. Anthropol. Archaeol. 11, 360-401.

Hildebrandt, W.R., Jones, T.L., 2002. Depletion of prehistoric pinniped populations along the California and Oregon coasts: were humans the cause? In: Kay, C.E., Simmons, R.T. (Eds.), Wilderness and Political Ecology: Aboriginal Influences and the Original State of Nature. University of Utah Press, Salt Lake City, pp. 72 110.

Hildebrandt, W.R., Jones, D.A., Carpenter, K., 2002. Prehistoric Coastal Occupations at Arroyo de los Chinos; Archaeological Test Excavations at CA-SLO-273/H and CA-SLO-274, San Luis Obispo County, California. Far Western Anthropological Research Group. Copies available from South Central Archaeological Information Center, Department of Anthropology, University of California, Santa Barbara.

Hudson, T., Blackburn, T.C., 1982. The Material Culture of the Chumash Interaction Sphere. Santa Barbara Museum of Natural History, Santa Barbara.

Ingram, B.L., Southon, J.R., 1996. Reservoir ages in eastern Pacific coastal and estuarine waters. Radiocarbon 38, 573-882.

Jackson, J.B.C., Kirby, M.X., Berger, W.H., Bjorndal, K.A., Botsford, L.W., Bourque, B.J., Bradbury, R.H., Cooke, R., Erlandson, J., Estes, J.A., Hughes, T.P., Kidwell, S., Lange, C.B., Lenihan, H.S., Pandolhi, J.M., Peterson, C.H., Steneck, R.S., Tegner, M.J., Warner, R.R., 2001. Historical overfishing and the recent collapse of coastal ecosystems. Science 293, 629-638.

James, S.R., 1997. Methodological issues concerning screen size recovery rates and their effects on archaeofaunal interpretations. J. Archaeol. Sci. 24, 385-397.

Jones, T.L., 1998. Archaeological Data recovery at the Toro Creek Site, CA-MNT-3, Monterey County, California. California Department of Transportation, Sacramento. Copies available from Northwest Archaeological Information Center, Department of Anthropology, Sonoma State University, Rohnert Park, California.

Jones, T.L., 1991. Marine-resource value and the priority of coastal settlement: a California perspective. Am. Antiq. 56, 419-443.

Jones, T.L., 1992. Settlement trends along the California coast. In: Jones, T.L. (Ed.), Essays on the Prehistory of Maritime California. Center for Archaeological Research at Davis Publication No. 10. University of California Davis, California, pp. $1-37$.

Jones, T.L., 1996. Mortars, pestles, and division of labor in prehistoric California: a view from Big Sur. Am. Antiq. 61, 243-264.

Jones, T.L., Codding, B.F., 2012. Sampling issues in evaluations of diet and diversity: lessons from Diablo Canyon. In: Glassow, M.A., Joslin, T.L. (Eds.), Exploring Methods of Faunal Analysis: Perspectives from California Archaeology. Cotsen Institute Press, University of California, Los Angeles, pp. 187-198.

Jones, T.L., Ferneau, J.A., 2002. Prehistory at San Simeon Reef: Archaeological Data Recovery at CA-SLO-179 and -267, San Luis Obispo County, California. San Luis Obispo County Archaeological Society Occasional Papers 16. San Luis Obispo.

Jones, T.L., Kennett, D.J., 1999. Late Holocene climate change and cultural ecology of the central California coast. Quatern. Res. 51, 74-82.

Jones, T.L., Van Bueren, T.M., Grantham, S., Huddleston, J., Fung, T., 1996. Archaeological Test Excavations for the Castroville Bypass Project, Monterey County, California. Office of Cultural Studies, California Department of Transportation. Copies available from Northwest Archaeological Information Center, Sonoma State University, Rohnert Park, CA

Jones, Terry L., Knight, D., Codding, B.F., 2015. Archaeological Investigations at CASLO-5, Diablo Canyon Lands, San Luis Obispo County, California: Final Report of the 2013 Cal Poly Field School and Mitigation Program. Prepared for the Pacific Gas and Electric Company. Copies available from the California Historic Resources Information System, Central Coast Information Center, University of California, Santa Barbara. 
Jones, T.L., Fitzgerald, R.T., Kennett, D.J., Miksicek, C.H., Fagan, J.L., Sharp, J., Erlandson, J.M., 2002. The Cross Creek Site (CA-SLO-1797) and its implications for new world colonization. Am. Antiq. 67, 213-230.

Jones, T.L., Davis, K., Farris, G., Fung, T., Grantham, S., Rivers, B., 1994. Toward a Prehistory of Morro Bay: Phase II Archaeological Investigations for the Highway 41 Widening Project, Caltrans Environmental Division. San Luis Obispo. Report on file with Caltrans, Environmental Division.

Jones, T.L., Brown, G.M., Raab, L.M., McVickar, J.L., Spaulding, W.G., Kennett, D.J., York, A. Walker, P.L., 1999. Environmental imperatives reconsidered: demographic crises in Western North America during the medieval climatic anomaly. Curr. Anthropol. 40, 137-170.

Jones, T.L., Porcasi, J.F., Erlandson, J.M., Dallas Jr., H., Wake, T.A., Schwaderer, R. 2008a. The protracted Holocene extinction of California's flightless sea duck (Chendytes lawi) and its implications for the Pleistocene overkill hypothesis. Proc. Natl. Acad. Sci. USA 105, 4105-4108.

Jones, T.L., Porcasi, J.F., Gaeta, J., Codding, B.F., 2008b. Diablo Canyon Fauna: a coarse-grained record of trans-Holocene foraging from the central California mainland coast. Am. Antiq. 73, 289-316.

Jones, T.L., Porcasi, J.F., Gobalet, K.W., Laurie, L.T., 2004. CA-SLO-215, a late milling stone site at Morro Bay, San Luis Obispo County, California. In: Bertrando, E., Levulett, V. (Eds.), Out of the Ice Age: Papers in Honor of Roberta Greenwood, San Luis Obispo County Archaeological Society Occasional Papers 17. San Luis Obispo, pp. 57-70.

Jones, T.L., Stevens, N.E., Jones, D.A., Fitzgerald, R.T., Hylkema, R.G., 2007. The central coast: a mid-latitude milieu. In: Jones, T.L., Klar, K.A. (Eds.), California Prehistory: Colonization, Culture, and Complexity. Altamira Press, Walnut Creek, California, pp. 125-146.

Joslin, T.L., 2006. Late Prehistoric Coastal Adaptations along the San Simeon Reef, San Luis Obispo County, California. Unpublished Master's thesis, Department of Anthropology, University of California, Santa Barbara.

Joslin, T.L., 2010. Middle and Late Holocene Hunter-Gather Adaptations to Coastal Ecosystems along the southern San Simeon Reef, California. Unpublished Ph.D. Dissertation, Department of Anthropology, University of California, Santa Barbara.

Jones, T.L., Waugh, G., 1995. Central California Coastal Prehistory: A View from Little Pico Creek. UCLA Institute of Archaeology, Los Angeles.

Kelly, R., 1996. Foraging and fishing. In: Plew, M.G. (Ed.), Prehistoric HunterGatherer Fishing Strategies. Boise State University Press, Boise, ID, pp. 208-214.

Kennett, D.J., 2005. The Island Chumash; Behavioral Ecology of a Maritime Society. University of California Press, Berkeley.

Kennett, D.J., Kennett, J.P., 2000. Competitive and cooperative responses to climate instability in coastal southern California. Am. Antiq. 65, 379-395.

Kennett, D.J., Voorhies, B., Wake, T.A., Martinez, N., 2008. Long-term effects of human predation on marine ecosystems in Guerrero. In: Rick, T.C., Erlanson, J. M. (Eds.), Human Impacts on Ancient Marine Ecosystems. University of California Press, Berkeley, pp. 103-124.

Kroeber, A.L., 1925. Handbook of the Indians of California. Smithsonian Institution, Bureau of American Ethnology Bulletin 78. Dover Publications, New York, Reprint (1976).

Kroeber, A.L., 1955. Nature of the land-holding group. Ethnohistory 2, 303-314.

Langenwalter, P.E., Huddleson, R.W., 1991. Vertebrate remains from CA-MNT-129, a late period coastal abalone processing site on the Monterey Peninsula. In: Archives of California Prehistory, vol. 33, pp. 45-60.

Lebow, C., Harro, D.R., Mckim, R.L., Hodges, C.M., Munns, A.M., Enright, E.A. Haslouer, L.G., 2015. The sudden flats site, a Pleistocene/Holocene transition shell midden on California's central coast. Calif. Archaeol. 7.

Lindstrom, S., 1996. Great Basin fisherfolk: optimal diet breadth modeling the Truckee River aboriginal subsistence fishery. In: Plew, M.G. (Ed.), Prehistoric Hunter-Gatherer Fishing Strategies. Boise State University Press, Boise, ID, pp. 114-179.

Love, M., 2011. Certainly More Than You Want to Know About the Fishes of the Pacific Coast: A Postmodern Experience. Really Big Press, Santa Barbara.

Magurran, A.E., 1988. Ecological Diversity and its Measurement. Princeton University Press, Princeton, New Jersey.

Magurran, A.E., 2004. Measuring Biological Diversity. Blackwell Publishing, Oxford.

Masters, P.M., Aiello, I., 2007. Postglacial evolution of coastal environments. In: Jones, T.L., Klar, K.A. (Eds.), California Prehistory: Colonization, Culture, and Complexity. Altamira Press, Walnut Creek, California, pp. 35-51.

Mason, R.D., Peterson, M.L., Tiffany, J.A., 1998. Weighing vs. counting: measurement reliability and the California school of midden analysis. Am. Antiq. 63, 303-324.

Mason, R.D., Peterson, M.L., Tiffany, J.A., 2000. Weighing and counting shell: a response to Glassow and Claassen. Am. Antiq. 65, 757-761.

McKenzie, D., 2007. Experimental Fishing Methods on the Northern Channel Islands: Testing the Relative Productivity of Bone Gorges and Incurving Shell Fishhooks. Unpublished Master's thesis, Department of Anthropology, University of California, Santa Barbara.

Mikkelsen, P., Hildebrandt, W.R., Jones, D.A., 2000. Prehistoric Adaptations on the Shores of Morro Bay Estuary: Excavations at Site CA-SLO-165, Morro Bay, California. San Luis Obispo County Archaeological Society Occasional Papers, No. 14.

Milliken, R.T., Nelson, J., Hildebrandt, W.R., Mikkelsen, P., 1999. The Moss Landing Hill Site: A Technical Report on Archaeological Studies at CA-MNT-234. Far Western Anthropological Research Group, Davis. Copies available from the Northwest Archaeological Information Center, Sonoma State University, Rohnert Park, CA.

Moratto, M.J., 1984. California Archaeology. Academic Press, New York.
Moyle, P.B., 2002. Inland Fishes of California. University of California Press, Berkeley.

Page, L.M., Espinosa-Perez, H., Findley, L.T., Gilbert, C.R., Lea, R.N., Mandrake, N.E. Mayden, R.L., Nelson, J.S., 2013. Common and Scientific Names of Fishes from the United States, Canada, and Mexico, seventh ed. American Fisheries Society Special Publication 34.

Pálsson, G., 1988. Hunters and gathers of the sea. In: Ingold, T., Riches, D. Woodburn, J. (Eds.), Hunters and Gatherers 1: History, Evolution, and Social Change. Oxford, Washington, DC, pp. 189-204.

Pletka, S., 2001. The economics of Island Chumash fishing practices. In: Arnold, J.E. (Ed.), The Origins of a Pacific Coast Chiefdom: The Chumash of the Channel Islands. University of Utah Press, Salt Lake City, pp. 221-244.

Plew, M.G. (Ed.), 1996. Prehistoric Hunter-Gatherer Fishing Strategies. Boise State University Press, Boise, ID.

R Core Development Team, 2014. R: A Language and Environment for Statistical Computing. Vienna, Austria.

Raab, L.M., Cassidy, J., Yatsko, A., Howard, W.J., 2009. California Maritime Archaeology: A San Clemente Island Perspective. Altamira Press, New York.

Raven, S., 1990. The Point of No Diminishing Returns: Hunting and Resource Decline on Boiju Islands, Torres Strait. Unpublished Ph.D. Dissertation. University of California, Davis.

Reitz, E.J., Andrus, F.T., Sandweiss, D.H., 2008. Ancient fisheries and human ecology of coastal Peru. In: Rick, T.C., Erlanson, J.M. (Eds.), Human Impacts on Ancient Marine Ecosystems. University of California Press, Berkeley, pp. 125-146.

Rick, T.C., 2007. The Archaeology and Historical Ecology of Late Holocene San Miguel Island. Cotsen Institute of Archaeology, University of California, Los Angeles.

Rick, T.C., Erlandson, J.M., 2000. Early Holocene fishing strategies on the California coast: evidence from CA-SBA-2057. J. Archaeol. Sci. 27, 621-633.

Rick, T.C., Erlandson, J.M., 2008. Human Impacts on Ancient Marine Ecosystems: A Global Perspective. University of California Press, Berkeley.

Rick, T.C., Vellanoweth, R.L., Erlandson, J.M., Kennett, D.J., 2002. On the antiquity of the single-piece shell fishhook: AMS radiocarbon evidence from the southern California coast. J. Archaeol. Sci. 29, 933-942.

Rick, T.C., Erlandson, J.M., Braje, T.J., Estes, J.A., Graham, M.H., Vellanoweth, R.L. 2008. Historical ecology and human impacts on coastal ecosystems of the Santa Barbara Channel region, California. In: Rick, T.C., Erlandson, J.M. (Eds.), Human Impacts on Ancient Marine Ecosystems: A Global Perspective. University of California Press, Berkeley, pp. 77-101.

Salls, R.A., 1988. Prehistoric Fisheries of the California Bight. Unpublished Ph.D. Dissertation, University of California, Los Angeles.

Salls, R.A., 1992. Prehistoric subsistence change on California's Channel Islands: environmental or cultural. In: Jones, T.L. (Ed.), Essays on the Prehistory of Maritime California, Center for Archaeological Research at Davis, vol. 10 University of California, Davis, pp. 157-172.

Schaffer, B.S., Sanchez, J.L.J., 1994. Comparison of 1/8-inch and 1/4-inch mesh recovery of controlled of small-to-medium-sized mammals. Am. Antiq. 59, 525-530.

Schmicking, D., 2012. An Analysis of Coastal Marine Impacts Caused by Prehistoric and Historic Fishing Practices in Morro Bay, CA. Unpublished Senior Thesis. Department of Social Sciences, California Polytechnic State University, San Luis Obispo.

Skinner, J.E., 1962. An Historical Review of the Fish and Wildlife Resources of the San Francisco Bay Area. California Department of Fish and Game Water Projects Branch Report No. 1.

Smith, E.A., Wishnie, M., 2000. Conservation and subsistence in small-scale societies. Annu. Rev. Anthropol. 49, 493-524.

Stahl, P.W., 1996. The recovery and interpretation of microvertebrate bone assemblages from archaeological contexts. J. Archaeol. Method Theory 3 31-75.

Strudwick, I., 1986. Temporal and Areal Considerations Regarding the Prehistoric Circular Fishhook of Coastal California. Unpublished Master's Thesis, California State University, Long Beach.

Thomas, D.H., 1969. Great basin hunting patterns: a quantitative method for treating faunal remains. Am. Antiq. 34, 392-401.

Thomas, D.H., 2008. Native American Landscapes of St. Catherines Island, Georgia. Part I. Anthropological Papers of the American Museum of Natural History, No. 88.

Turnbull, J., Gobalet, K.W., Gaeta, J.W., Des Lauriers, M.R., 2015. The Native American Fishery of Cedros Island, Baja California, and a comparison with the fisheries of the islands of the southern California Bight. J. Calif. Great Basin Anthropol. 39, 69-86.

Tushingham, S., 2009. The Development of Intensive Foraging Systems in Northwestern California. Unpublished Ph.D. Dissertation, Department of Anthropology, University of California, Davis.

Ugan, A., Bright, J., Rogers, A., 2003. When is technology worth the trouble? J Archaeol. Sci. 30, 1315-1329.

Wagner, H.R., 1924. The Voyage to California of Sebastian Rodriguez Cermeño in 1595. Calif. Hist. Soc. O. 3 (1), 3-24.

Whitaker, A., 2010. Prehistoric behavioral depression of cormorant (Phalacrocorax spp.) on the northern California coast. J. Archaeol. Sci. 37, 2562-2571.

Whitaker, A., Byrd, B.F., 2012. Boat-based foraging and discontinuous prehistoric red abalone exploitation along the California coast. J. Anthropol. Archaeol. 31, 196-214.

Zohar, I., Belmaker, M., 2005. Size does matter: methodological comments on sieve size and species richness in fishbone assemblages. J. Archaeol. Sci. 32, 635-641. 